Published in final edited form as:

Cancer Metastasis Rev. 2015 March ; 34(1): 53-74. doi:10.1007/s10555-014-9540-2.

\title{
Targeted Immune Therapy of Ovarian Cancer
}

\author{
Keith L. Knutson, Ph.D. ${ }^{1,2,3}$, Lavakumar Karyampudi, Ph.D. ${ }^{1}$, Purushottam Lamichhane, \\ B.Sc. ${ }^{1,2}$, and Claudia Preston, M.D. ${ }^{2}$ \\ ${ }^{1}$ Cancer Vaccines and Immune Therapies Program, The Vaccine and Gene Therapy Institute of \\ Florida, Port St. Lucie, Florida 34949 \\ ${ }^{2}$ Department of Immunology, Mayo Clinic, Rochester, Minnesota 55905 \\ ${ }^{3}$ Center for Molecular Biology and Biotechnology (CMBB) Florida Atlantic University, Boca Raton, \\ FL 33431
}

\section{Abstract}

Clinical outcomes, such as recurrence free survival and overall survival, in ovarian cancer are quite variable, independent of common characteristics such as stage, response to therapy and grade. This disparity in outcomes warrants further exploration and therapeutic targeting into the interaction between the tumor and host. One compelling host characteristic that contributes both to the initiation and progression of ovarian cancer is the immune system. Hundreds of studies have confirmed a prominent role for the immune system in modifying the clinical course of the disease. Recent studies also show that anti-tumor immunity is often negated by immune regulatory cells present in the tumor microenvironment. Regulatory immune cells also directly enhance the pathogenesis through the release of various cytokines and chemokines, which together form an integrated pathologic network. Thus, in the future, research into immunotherapy targeting ovarian cancer will probably become increasingly focused on combination approaches that simultaneously augment immunity while preventing local immune suppression. In this article, we summarize important immunological targets that influence ovarian cancer outcome as well as include an update on newer immunotherapeutic strategies.

\section{Keywords}

Cytokines; T cells; macrophages; single nucleotide polymorphisms; dendritic cells; inflammation; monoclonal

\section{Introduction}

Ovarian cancer has the highest mortality rate of the cancers unique to women. According to Siegel and colleagues, in 2012 there were an estimated 22,240 new cases of ovarian cancer and estimated 14,030 deaths [1]. Moreover, the majority (65\%-75\%) of women with ovarian cancer are diagnosed with advanced stage disease (III and IV), and only about 15\%-20\% of these women are free of disease recurrence at ten years [2-4]. Major subtypes of ovarian

Correspondence: Keith L. Knutson, PhD, Cancer Vaccines and Immune Therapies Program, Vaccine and Gene Therapy Institute of Florida, 9801 SW Discovery Way, Port St. Lucie, FL 34949. 
cancer include serous, endometrioid, clear cell and mucinous histologies, with heterogeneous characteristics [5]. Nevertheless, there are unique features about ovarian cancer that may shed light on its basic biology, hopefully leading to improvements in therapeutics and outcome. One of those unique features is the complex interaction of the immune system in both ovarian cancer initiation and progression which has been well documented over the last two decades and is the central topic of this review. This review covers a broad range of topics related to the immunobiology and immunotherapy of ovarian cancer.

\section{Immune System Basics}

The immune system is constituted by a heterogeneous population of both cellular and molecular effectors which function in an organized and integrated manner to eradicate disease and maintain the overall health of the host while minimizing off-target activity (e.g. autoimmunity). The immune system is typically divided into two different, but interacting, systems referred to as the innate and the adaptive mechanisms. The innate immune system is the first line of defense that consists of a group of cellular and humoral factors. The cellular component of innate immunity includes natural killer (NK) T cells, mast cells, eosinophils, basophils, macrophages, neutrophils and dendritic cells, while the humoral factors primarily include cytokines and complement. The major functions of the innate immune system include recruiting immune cells into sites of infection, activation of complement, identification of foreign substances, and preparation and activation of the adaptive immune systems. Innate responses are immediate, maximal, and antigen-independent. In the absence of stimulation, non-activated innate cells are well known to maintain tolerance and prevent inappropriate immune activation. The adaptive immune response involves both $\mathrm{T}$ and $\mathrm{B}$ lymphocytes. T lymphocytes produce cytokines or cytolytic molecules, while B cells produce antibodies. Primary adaptive immune responses usually develop after one week and are highly antigen-specific. Like the innate immune system, subsets of lymphocytes, e.g. regulatory $\mathrm{T}$ cells (Treg), are also known to regulate immunity and prevent autoimmunity. Lastly, another key feature of the adaptive immune response is generation of immune memory and the resulting rapid and robust responses to previously encountered antigens, a fundamental reason for the widespread clinical success of vaccines.

\section{Inflammation in Ovarian Cancer Initiation}

Some studies suggest that chronic immune activation and inflammation is an important mediator of ovarian carcinogenesis [6]. Several theories exist regarding the causes of chronic inflammation. The incessant ovulation model postulates that multiple rounds of ovulation and the subsequent inflammatory response to the wound leads to an oncogenic event(s). Many epidemiologic studies have implicated that increased number of ovulations is a risk factor for ovarian cancer development [7]. For example, protection from ovarian cancer has been observed in association with increased parity [8,9], oral contraceptive use [10, 11], breast feeding [12, 13], older age at first menses (for premenopausal women) [14], all of which impact total lifetime number of ovulations. One of these studies, which has been further substantiated by more recent investigations, found protective effects of "anovulatory time" by combining information on both increased oral contraceptive use and parity as well 
as age at first and last menses [15] supporting the theory of incessant ovulation as a mechanism of oncogenesis. Recent studies support a role of macrophages in inducing DNA damage during repair of the wound left by ovulation. For example, one study found not only that superovulated mice had elevated macrophage counts in their oviducts, but that oxidative stress induced by hydrogen peroxide or macrophage-secreted mediators initiated DNA damage in immortalized baboon tubal epithelial cell lines [16].

Inflammation may also be due to chronic exposures to external triggers of immunity leading to persistent infiltration of immune cells that cause injury to surrounding epithelium, damage DNA through release of reactive oxygen species, or produce cytokines that promote proliferation. One proposed environmental exposure shown to induce inflammation in animal models is talcum powder [17]. Composed primarily of magnesium silicate, this moisture absorbing substance has been linked to ovarian cancer risk in a number of studies $[6,18-20]$ although selection bias and confounding were strong concerns for the studies that found these associations $[21,22]$. The strong correlation between endometriosis and ovarian cancer also supports the chronic inflammation hypothesis. Endometriosis involves endometrial cells growing outside of the uterus and has been investigated extensively as a risk factor for ovarian cancer. Several epidemiologic studies have found an association between history of endometriosis and invasive epithelial ovarian cancer and most recently a pooled analysis of 13 case-control studies demonstrated that history of endometriosis increased the risk of clear cell, low grade serous, and endometrioid invasive ovarian cancers, but not mucinous or high grade serous ovarian cancers [23].

Exposure to pathogens might also cause chronic inflammation that would aid in tumor promotion and progression. Retrograde menstruation provides a potential mechanism by which pathogens could reach fallopian tube epithelial cells to establish infection [24]. While there is little evidence that specific pathogens contribute to most ovarian cancer cases, some studies have found a relationship between pelvic inflammatory disease and ovarian cancer risk. $[6,25,26]$. Consistent with the idea that chronic inflammation - whether mediated by ovulation induced damage, foreign agents, or both - is an underlying cause of ovarian cancer, non-steroidal anti-inflammatory drugs (NSAIDs) have been associated with a decreased risk of ovarian cancer but results have been inconsistent [6, 20, 27]. Studies evaluating inherited single nucleotide polymorphisms (i.e. SNPs) support a role for chronic inflammation. SNPs in genes can affect expression and function of their protein products [28]. Apart from typical epidemiologic approaches, the ability to examine the impact of genetic variation in disease processes over the past decade represents a significant advance in understanding the role of the immune system in disease risk. While genome wide association studies to date have found significant associations with ovarian cancer and single nucleotide polymorphisms (SNPs) in genes that are not directly immune-related [29-31], several groups have conducted candidate gene studies that evaluated SNPs in immunerelated genes, including NFKB1 [32], NOD2 [33], NFKBIA [34], CASP8 [35, 36], MBL2 [37], PTGS2 [38], ALOX5 [39], IL1A [39], ILIR1 [40], TNFS10 [41] and IL18 [42]. While this is not an all-inclusive list of studies that have assessed immune related SNPs in relation to ovarian cancer risk, it does start to provide insight into contribution of immune genes in this disease. 
The suggestion that initiation of ovarian cancer is mediated by inflammation is supported by studies examining blood-based markers of inflammation including C-reactive protein (CRP). CRP levels in the blood rise in response to IL-6 released during local inflammatory processes, [43]. Its physiological role is to bind to phosphocholine on the surface of dead cells in order to activate the complement system. CRP protein levels in the blood are associated with a wide range of diseases, such as diabetes and atherosclerosis [44]. Toriola showed in the Finnish Maternity Cohort case-control study that there was an association between elevated pre-diagnostic CRP levels in the blood and ovarian cancer ( $\mathrm{OR}=2.0,95 \%$ CI: 1.1-3.4) [45]. In another analysis, which included participants from three pooled prospective nested cohort studies, Lundin and colleagues reported a similar finding in which high levels of CRP were associated with a 4.4 fold increased risk of developing ovarian cancer [46]. The increased availability of assays to determine cytokine levels has recently led to studies evaluating other circulating markers of inflammation. Using a nested approach with three prospective cohort studies, Clenenden and colleagues found that IL-6, as well as IL-2, IL-4, IL-12, and IL-13 levels were associated with increased risk of developing epithelial ovarian cancer [47]. Overall, the studies demonstrating that elevated CRP and IL-6 levels are associated with an elevated risk of ovarian cancer support a role for inflammation, likely subclinical, in initiating the disease.

In summary, there is support of the notion that chronic inflammation in the reproductive tract is involved in ovarian cancer development. Unfortunately, to the best of our knowledge, no studies have been reported which directly compare in either a prospective cohort or case-control setting that smoldering subclinical inflammation drives the development of neoplasia of the ovary. With high-throughput genetic approaches having been developed in recent years, such as genome-wide SNP analysis and multiplexed cytokine analysis, it has become possible to interrogate mechanisms at the population level. The studies being largely association-based remain difficult to interpret at present, particularly the genetic studies; however, the identified targets provide a future pipeline of possible immunologic targets to prevent ovarian cancer onset (Figure 1).

\section{Microenvironment: Role of Tumor Infiltrating Immune Cells in Disease Progression}

A completely different kind of inflammation follows tumor development [48]. Observations that date back several decades have established that there are natural immune responses to ovarian tumors and these immune responses have a profound impact on the clinical course of the disease. Although infiltration of immune effectors into ovarian cancers was observed as early as 1982 by Haskill and colleagues [49] it would not be until nearly two decades later that the prognostic significance of these cells was appreciated. In their seminal publication in 2003, Zhang and colleagues showed that $\mathrm{T}$ cell infiltration into ovarian tumors was associated with improved survival [50]. Among 74 patients with complete clinical responses after debulking and platinum-based therapy, the five-year survival rate was an extraordinary $73.9 \%$ among those patients with $\mathrm{CD}^{+} \mathrm{T}$ cells within their tumor compared to $11.9 \%$ among patients without infiltrating $\mathrm{T}$ cells [50]. This study also revealed that in tumors with high numbers of tumor-infiltrating T cells, the expression of monokines induced by IFN- $\gamma$, 
macrophage-derived chemokines, and secondary lymphoid-tissue chemokines were significantly increased as compared with tumors lacking $\mathrm{T}$ cells, which may represent novel targets for improving anti-tumor immunity [50].

CD8 cytotoxic T lymphocytes (CTL), thought to be the primary mediators of anti-tumor immune responses, recognize antigens displayed in the context of major histocompatibility complex (HLA) class I molecules expressed on ovarian cancer cells. To examine a role of CTL in ovarian cancer, Sato and colleagues studied 117 ovarian cancer cases and found improved survival in patients who had higher numbers of infiltrating CD8+ T cells compared to patients without infiltrating CD8 T cells (median survival 55 vs. 26 months) [51]. These findings were largely confirmed by Leffers [52]. Transcriptomic profiling of serous ovarian tumors with high and low CD8 T cell infiltration found two genes differentially expressed in cancers with high versus low CD8 T cell infiltration, namely, interferon regulatory factor 1 (upregulator of MHC class I) and C-X-C chemokine receptor 6 (enhances $\mathrm{T}$ cell proliferation) $[53,54]$.

The role of CD4 helper T cells is less clear due to shared expression with regulatory $\mathrm{T}$ cells (Tregs). Both Sato and Milne observed similar outcomes among patients with or without CD4+ T cell staining within tumors $[51,55]$ while Le Page observed that increased CD4+ cells in 199 high grade serous cancers were associated with improved survival [56]. Kryczek and colleagues found that high levels of IL-17 ascites were associated with greatly improved outcome suggesting that Th17 cells, a subset of CD4 helper T cells that produce IL-17, may have a direct role in eradicating tumor [57]. Given the abundant expression of IL-17 among innate immune effectors, it is difficult to draw a conclusion as to whether intratumoral Th17 cells might impact the clinical course of the disease [58]. However, the fact that levels of Th17 cells have a strong inverse correlation with Tregs, suggests that they might be associated with tumor eradication [57].

Other specific subsets of potential antitumor immune effectors have also been studied but with less than clear results. The generation of antibody responses to ovarian cancer is a common observation suggesting a role for B cells in disease prognosis [59-61]. Although antibody-secreting B cells do not need to be at the tumor site to exert antitumor activity, studies evaluating whether B cell infiltration is associated with improved survival show mixed results [55, 62]. Another recent evaluation of infiltrating cells constructed from tumors of women with high grade serous ovarian cancer from 3 patient cohorts, found that infiltration of tumors by both CD8+ and CD20+ (B cell marker) lymphocytes (the two subsets were correlated and often found near each other within the tumor) was associated with increased survival [63]. The CD20+ B cells did not express CD27, a memory B cell marker, but IgG sequencing suggested they had been exposed to antigen. The authors hypothesized that these cells are likely involved in modulating CTL recruitment or activity [63].

Natural killer (NK) cells are also found in the ovarian cancer microenvironment. NK cells are a group of lymphocytes that have two different mature phenotypes, either CD16+ CD56 ${ }^{\text {dim }}$ NK cells which are highly cytolytic and found in the periphery, or CD16CD56 ${ }^{\text {bright }} \mathrm{NK}$ cells which are less cytolytic and found in the secondary lymphoid tissue 
[64]. CD16+ CD56 ${ }^{\mathrm{dim}} \mathrm{NK}$ cells have two types of surface receptors: activating (i.e., NKG2D) receptors and inhibitory (i.e., KIR) receptors, and can lyse cells without having to recognize specific antigens [65]. The balance between inhibitory and activating signals through the different NK receptors is important in the NK cell activation process. NK cells can also be activated in an antigen-dependent manner to mediate antigen-dependent cellular cytotoxicity, which requires antibody binding to Fc receptors on the NK cells. The activating NKG2 receptors bind to stress ligands such as MICA, MICB, and ULBP1-3, while KIR receptors bind to major histocompatibility complex class I and class I associated ligands [65, 66]. Nearly all ovarian cancers express the NK ligands MICA, MICB and ULBP2 [67]. Despite the potential antitumor activity, increased numbers of NK cells in peritoneal and pleural effusions of metastatic ovarian carcinoma has been associated with poor rather than good prognosis [62].

Immune evasion in ovarian tumors involves a complex array of immune suppressive factors and cells that effectively halt the generation and clonal expansion of anti-tumor immunity (Figure 2). Genetic changes also occur, permitting the tumor cells to be ignored by the immune response. Immune suppression is mediated by factors released from the tumor or by infiltration of the tumors by a variety of either lymphoid or myeloid derived suppressor or regulatory cells. The role of $\mathrm{CD}^{+}$Tregs in ovarian cancers is well characterized. Tregs are a heterogeneous $\mathrm{T}$ cell subpopulation whose primary function is suppression of immune responses. CD4 ${ }^{+}$Tregs are either thymically-matured or induced from naïve CD4 T cells $[68,69]$. While induced Tregs produce immune-suppressive soluble mediators such as TGF$\beta$ and IL-10 to mediate their inhibitory activities and block T cell proliferation, thymicallymatured Treg cells use cytokine-dependent, cell contact-dependent, or a cytokine/cellular contact-dependent mechanisms to halt $\mathrm{T}$ cells response [68]. Tumors can increase the numbers of Tregs in the peripheral blood of cancer patients as reported for several tumor types, including ovarian [70-73]. Tumors can also recruit or induce Treg tumor infiltration. The connection between pathogenesis of Tregs and prognosis in ovarian cancer was first suggested by Curiel who showed that infiltration of Tregs (as assessed by CD4 and CD25 staining) was associated with poor patient survival [74]. Several other manuscripts subsequently published, also demonstrated the importance of Tregs in ovarian cancer pathogenesis and outcome. Wolf and colleagues showed that patients with low levels of intratumoral Foxp3 message had substantially improved survival compared to patients with high levels [75]. Our group recently demonstrated that high grade serous ovarian cancer is infiltrated with $\mathrm{CD} 4^{+} \mathrm{CD} 25^{+} \mathrm{Foxp} 3^{+}$Tregs and that a low ratio of infiltrating CD8 $\mathrm{T}$ cells and these triple stained Tregs is associated with poor survival [73].

In addition to lymphoid-derived regulatory cells, the myeloid arm of the immune system can give rise to multiple regulatory species including macrophages, dendritic cells, and myeloid derived suppressor cells (MDSCs). Macrophages normally infiltrate healthy tissue where they carry out various functions such as clearing dead cells and surveying for infectious agents. When faced with an infectious challenge, macrophages typically activate and differentiate into an activating phenotype often referred to as an M1 phenotype. Macrophages that infiltrate tumors, in contrast, differentiate into an alternative phenotype referred to as an M2 phenotype which is characterized by tissue regeneration responses and local immune suppression [76]. Hagemann first demonstrated that ovarian cancer cells can 
direct macrophages to become M2 [77]. Ko later showed that this was due to the high level expression of the homeobox transcription factor, HOXA9 [78]. A few studies have assessed, using pan macrophage CD68 staining, whether there is an association between macrophages and ovarian cancer survival, finding no effect [55, 79]. However, one study that assessed M2 marker, CD206, found that patients with tumors that had a higher proportion of CD206+ relative to total CD68+ cells also had an increased risk of disease progression [56]. In agreement, Lan and colleagues reported a similar finding using CD163, another M2 macrophage marker [80]. Thus, strategies aimed at selectively depleting M2 macrophages may aid in immune-mediated tumor regression. Indeed, we have recently shown in murine models that co-immunization targeting both oncogenes and M2 macrophages can lead to regression of established tumors [81].

DCs are classified into two general types: plasmacytoid DCs (pDCs) which are

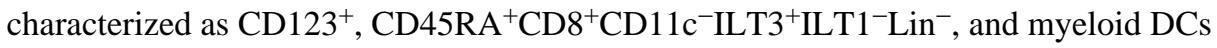

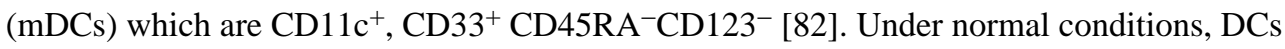
are present in the body in an immature form and are responsible for detecting danger and sampling of antigens in various tissues. Upon detection of danger through their pathogenassociated molecular pattern (PAMP) receptors or danger-associated molecular pattern (DAMP) receptors, DC mature and migrate to the lymph nodes to activate $\mathrm{T}$ helper cells and CTL [82]. Although tumors are able to produce danger signals, they are ineffective in inducing DC maturation and trafficking to lymph nodes which is thought to be due to tumorinduced alterations in DC differentiation, thus reducing the number of functional cells available for effective $\mathrm{T}$ cell activation [83]. For example, ovarian cancers secrete large amounts of IL-10 which promotes redifferentiation of mDCs to an aberrant phenotype with reduced $T$ cell activation properties [83]. In murine modeling studies, our group has found that suppressor mDCs within ovarian cancers are induced to express high levels of PD-1 which reversibly suppresses expression of co-stimulatory molecules, reduces migration, and blocks responsiveness to danger signals [84]. More recent work also shows that PD-1 ligation of infiltrating mDCs suppresses IL-7 receptor expression on infiltrating T cells, thereby limiting persistence of T cells in the tumor bed [85]. Blockade of PD-1 on DCs results in reversal of immune suppression. These mDCS also express high levels of PD-L1 which is the primary means by which these DCs suppress T cell activation. Interestingly, PD-L1 is not downregulated on mDCs when DC-bound PD-1 is blocked even though the immune suppressive properties of the $\mathrm{mDC}$ are reversed suggesting that the immunogenic properties of tumor infiltrating mDCs is regulated by a balance of immune suppressive or activating molecules. mDCs in their immature states are also known promoters of angiogenesis and vasculogenesis during tumor growth [86-88].

Human ovarian cancers have also been observed to recruit immature pDCS which induce T cells to release large amounts of IL-10 preventing local T cell activation [89]. This recruitment is thought to involve SDF-1 (produced by the tumor) ligation of CXCR4. CXCR4 plasmacytoid precursor cells (preDC2s) are attracted into the tumor microenvironment by tumor derived stromal cell-derived factor 1 (SDF-1). Induction of IL-10 is due, at least in part, to local induction of $\mathrm{IL}-10^{+}$regulatory CD8 T cells [90]. Overall, the DC component of ovarian cancers remains an intriguing and underexplored area of ovarian cancer research and could represent a therapeutic target. This concept is borne out 
of recent murine modeling studies demonstrating improved antitumor immunity following specific depletion of DCs [91].

Apart from pDCs and mDCs, there is another subset of myeloid-derived cells, called myeloid-derived suppressor cells (MDSCs), that have an increased ability to block local and systemic immune activation [92]. This is a heterogeneous population consisting of macrophages, DCs and granulocytes at early stages of differentiation [87]. MDSCs are classified into two subpopulations, granulocytic and monocytic MDSCs which, in mice but not humans, are uniquely identified by co-expression of CD11b and Gr1 [93]. MDSCs are known to expand dramatically under various health conditions such as tumor growth, inflammation, and infection [87, 94, 95], and may have a role in immune suppression of ovarian cancer in murine models; however, their relevance in human ovarian cancers remains uncertain [96].

Aside from the recruitment of suppressive cells into the tumor microenvironment, tumor cells themselves express a variety of molecules that directly block immune responses. PD$\mathrm{L} 1$ is expressed on the surface of several gynecological cancers including ovarian and is associated with poor overall survival in ovarian cancer [97-99]. Its ligand, PD-1 is expressed on, not only on infiltrating $\mathrm{mDCs}$ but also on various other adaptive immune effectors, notably CD4 and CD8 T cells, where it negatively regulates cell activation in cancers including ovarian [100-103]. Another suppressive molecule is MUC16 (CA-125). MUC16 augments the immune suppressive tumor microenvironment by inhibiting the activity of NK cells [104-107]. A recent study by Gubbels and colleagues sheds more light into the role and importance of MUC16 on cancer cells [106]. They showed that MUC16 acts as an inhibitor of the NK-tumor conjugation. NK cells killed cells expressing low levels of MUC16 more effectively, with $\sim 20 \%$ more NK cell lysis and a 2-3 fold increase in NK leukemia cells lysis when compared with lysis of cells with high MUC16 expression [106]. Furthermore, a recent study by Krockenberger and colleagues showed that macrophage migration inhibitory factor (MIF, inducer of inflammation and promoter of tissue repair) inhibits the antitumor immune response against ovarian cancer cells by down regulating NKG2D receptor in NK cells [108].

Another mechanism by which several different types of immune cells are suppressed in the tumor microenvironment is through the production of indoleamine 2, 3-dioxygenase (IDO) $[109,110]$. IDO mediates immune tolerance in T cells and natural killer cells by consuming tryptophan and forming kynurenine resulting in inhibition of proliferation and functional impairment [111-115]. It also promotes a regulatory T-cell phenotype [116-118]. IDO is expressed by many tumor types, including ovarian cancer [119-121]. Takao and colleagues reported protein expression of IDO in serous (57.5\%), clear cell (49.2\%), and endometrioid (73.3\%) ovarian adenocarcinomas [121]. They additionally found an association between IDO staining in ovarian cancer tumors and lower overall survival for serous ovarian cancer patients with advanced stage disease who had optimal surgery and were given first-line paclitaxel-carboplatin chemotherapy [121]. Inaba and colleagues reported a similar association between high compared to low expression of IDO in ovarian cancer tumors of mixed histology, stage and grade and lower overall and progression-free survival. In addition, they found reduced numbers of CD8+ TILs in the tumors expressing high IDO 
[119]. IDO plays an important role in immune suppression and tumor immune evasion and may have potential as a therapeutic target. Indeed, several studies have investigated the efficacy of blocking IDO in tumor models.[119, 122-126]. Several matters complicate targeting IDO, however. For example, there are two IDO genes(IDOI and IDO2) which produce products that contribute to tryptophan metabolism (reviewed in Soliman [127]). Additionally, two isomers of the most commonly studied inhibitor, 1-methyl-tryptophan (1MT), exist [128, 129]. Many early studies used a racemic mixture of the two, however, a study by Metz found that the L isomer of 1MT, preferentially inhibits IDO1 while the D isomer preferentially inhibits IDO2 [130]. In vitro studies demonstrated that the L isoform was superior in restoring $\mathrm{T}$ cell and antigen presenting functions in vitro. However, the $\mathrm{D}$ isomer, in conjunction with conventional chemotherapy drugs, was more potent than the $\mathrm{L}$ isomer in in vivo studies [130]. Currently, which isoform to target is not well understood. Third, in addition to IDO1 and IDO2, increased expression of TDO (tryptophan 2, 3dioxygenase), normally expressed in the liver, has been reported in several different tumor types, including ovarian cancer [131]. Kynurenin, one of the metabolites of TDO binds aryl hydrocarbon receptor, causing this transcription factor to translocate to the nucleus and activate several genes, including those activating Tregs [131, 132]. The structure of TDO differs greatly from IDO1 and IDO2 and IMT is unable to inhibit the enzyme. Pilotte and colleagues found that a derivative (LM10) of a known TDO inhibitor (680C91) was able to prevent the growth of TDO expressing tumors [133].

\section{Pathologic Cytokine Interactions: TNFa, CXCL12, IL-6 axis}

In contrast to agents that directly increase or decrease specific immune cell subsets, another concept that has recently been introduced is the disruption of integrated cytokine networks. One integrated cytokine network for which there is considerable published support, termed the 'TNF network' - consisting of TNF, CXCL12, and IL-6 - was recently identified by Kulbe and colleagues in human ovarian cancer specimens (Figure 3) [134]. TNFa expression and function in cancers including ovarian cancer has long been studied and its expression is highly correlated with increased expression CXCL12 and IL-6, and this results in the ability of TNFa to mediate a variety of effects [135]. The effect of TNFa on a tumor depends on both timing and dose. A single, high-dose exposure promotes tumor regression while chronic, low-dose expression of TNFa is tumor promoting $[136,137]$. In vitro studies of ovarian cancer cell lines using RNAi to decrease expression of TNFa did not result in any changes in proliferation or apoptosis. However, when the same cells were injected in vivo, a decrease in tumor burden, restricted distribution, and increased apoptosis was evident [135]. Kulbe and colleagues suggest that these differential effects of TNFa blockade in vivo are due to disruption of a multi-cytokine network constituted by TNFa, CXCL12 and IL-6 that results in reduced angiogenesis, reduced infiltration of regulatory cells and NOTCH signaling [134].

High level expression of IL-6 has been found in ovarian cancer [138]. IL-6 directly promotes cancer growth and progression through several mechanisms including proliferation, angiogenesis, and decreased sensitivity to apoptotic signals [139, 140]. High levels of IL-6 in the serum of ovarian cancer patients have been associated with shorter survival [141, 142]. Additionally, high levels of IL-6 are often detected in the malignant 
ascites of ovarian cancer patients [143]. IL-6 mediates its pathologic effects on cancers via several mechanisms, including activation of the growth promoting JAK/STAT, PI3K/Akt, and Ras/MEK/IRK pathways [141, 142, 144, 145]. IL-6 is also thought to be important in the generation of thrombocytosis (elevated platelets) commonly observed in ovarian cancer patients and associated with shortened survival [146]. Thus, IL-6 has emerged as a logical candidate for targeted therapy [reviewed in [139, 147]].

CXCR4 has been previously reported to be constitutively expressed in ovarian cancer and its ligand, CXCL12 is secreted by cells in the tumor microenvironment in addition to ovarian cancer cells [reviewed in [148]]. Ligation of CXCR4 has several effects, including stimulation of proliferation, vascular endothelial growth factor-mediated angiogenesis, and recruitment of immune cells [149-152]. In immunocompetent mouse model studies blockade of the CXCL12/CXCR4 signaling increased survival, increased tumor cell apoptosis, and reduces Treg infiltration [152].

\section{Novel Targets Identified by Analysis of Genetic Variation}

Recent evaluations of associations between genetic variation and progression in ovarian cancer could also provide clues as to potential immune targets. Goode and colleagues evaluated germline variation in 26 inflammation-related genes in a population of 325 patients with ovarian cancer [153]. Of those 26 genes, SNPs in CCR3, CCL2, IL1B, IL18, and $A L O X 5$ were related to survival in patients. Both arachidonate 5-lipoxigenase (ALOX5) which converts arachidonic acid into leukotrienes and IL-18 which promotes IFN- $\gamma$ production in NK and TH1 cells which were previously associated with increased risk of developing ovarian cancer as described above. The chemokine receptor CCR3, the product of $C C R 3$, binds and responds to a variety of chemokines, including CCL11, CCL26, CCL7, CCL13, and CCL5. The receptor is involved in chemotaxis in a wide variety of leukocytes such as CD4 T cells. CCR2 (monocyte chemotactic protein 1) is important for recruitment of monocytes (macrophages) to sites of inflammation. ILIB encodes IL1beta, a pro-

inflammatory cytokine that also has multiple effects on both the immune system and directly on ovarian cancer cells [154]. In another prospective study of 147 advanced ovarian cancer patients, an association between two ILIO promoter polymorphisms and disease-free and overall survival overall survival was observed, possibly due to its relationship with optimal tumor debulking [155]. Lastly, in addition to cytokines, genes encoding other modulators of the immune system have been implicated in disease recurrence and progression. TLR4, normally expressed at high levels on immune cells, detects lipopolysaccharide from Gramnegative bacteria and is important in the activation of the innate immune system through $\mathrm{NF}-\kappa \mathrm{B}$. In a clinical outcomes study of ovarian cancer patients, a putative microRNA binding site polymorphism in Toll-like receptor 4 (TLR4) (rs7869402) was associated with inferior survival and response to treatment [40]. We recently analyzed expression quantitative trait loci (eQTL) and sequence-based tagging single nucleotide polymorphisms (tagSNPs) for 79 Treg associated genes in invasive ovarian cancer cases. We found that poorer survival was associated with minor alleles at SNPs in TNFRSF18 (OX40) in the mucinous subtype, in $C D 80$ in the endometrioid subtype, $\mathrm{CD} 25$ in endometrioid subtype, and CTLA4 in the clear cell subtype $[156,157]$. As the products of these genes are known to affect induction, trafficking, or immunosuppressive function of immune cells, these results 
suggest the need for follow-up phenotypic studies and suggest that the role of the immune system may differ among the various subtypes of cancer.

\section{Targeted Antigens in Ovarian Cancer}

Many studies now have shown heterogeneity of human ovarian cancers with respect to infiltration by immune effectors which are often associated with favorable outcome suggesting that ovarian cancer activates an antigen-specific immune response which eliminates tumor cells or suppresses growth. Whether or not immune effectors in the tumor are antigen specific and which antigens are tumor rejection antigens remain largely unanswered with minor exception. Two groups have shown that a fraction of CD4 ${ }^{+} \mathrm{TIL}$ are specific for NY-ESO-1 and show evidence of Th1 skewing but with an exhausted (i.e. PD- $1^{+}$) phenotype $[103,158]$. Nelson recently showed that, although at low frequency, ovarian cancer patients generate T cells responses to mutated proteins [159]. Despite that, several ovarian cancer antigens have been identified and in recent years, several studies have demonstrated that patients who have ovarian cancer respond naturally to these antigens as measured in the peripheral blood.

One of the initial studies that the effector $\mathrm{T}$ cells associated with ovarian cancers were specific for overexpressed antigens in the tumor came from Ioannides' laboratory where it was found that ascites-derived tumor-associated lymphocytes (TAL) contains CD8 T cells capable of recognizing the human epidermal growth factor receptor 2 (HER-2/neu) derived peptide, p971-980 [160]. HER-2/neu protein, also known as HER2, ErbB-2 and c-erbB2 is a transmembrane glycoprotein $(185 \mathrm{kDa})$ that is part of the epidermal growth factor receptor family that also includes EGFR-1, HER-3, and HER-4. HER-2/neu is comprised of a large extracellular domain, a short hydrophobic transmembrane domain, and a cytoplasmic intracellular domain containing tyrosine kinase activity [161]. HER-2/neu is an attractive immunologic target because of its low level expression in peripheral tissues and its biologic relevance. Estimates of the percentage of ovarian tumors with HER-2/neu expression have been variable, ranging from 5\% to 66\% [162-165]. Data in the past decade have been somewhat contradictory regarding to the prognostic relevance of HER-2/neu gene amplification or protein overexpression in ovarian cancer $[163,165,166]$.

Insulin-like growth factor binding proteins (IGFBP) are a family of six binding proteins that have 50\% homology with each other and have binding and regulatory properties for insulinlike growth factor 1 (IGF-1) and insulin-like growth factor 2 (IGF-2), therefore having a role in cell proliferation, differentiation and apoptosis. All six family members are secreted and expressed in normal ovarian tissue, although previous studies have shown that IGFBP-2 serum levels and expression to be significantly increased in ovarian cancer tissue in comparison with controls [167-170]. We revealed for the first time that IGFBP-2 elicits an in vivo antigen-specific CD4 T cell immunity in patients with ovarian cancer [171]. In that study, $\mathrm{T}$ cells from $>15 \%$ of the patients elicited a response against four HLA-DRdegenerate IGFBP-2 epitopes compared with controls. The pool of four IGFBP-2 peptides covered the vast majority ( $\sim 80 \%$ ) of patients regardless of HLA-DR genotype. 
Of eleven transmembrane mucins identified to date, three (MUC1, MUC4, and MUC16) have been well characterized and shown to be overexpressed in ovarian cancer [172-175]. MUC16 (CA-125) is the largest membrane-bound mucin protein; it is expressed on the surface of ovarian cancer cells and shed to the bloodstream and peritoneal cavity after proteolytic cleavage. Overexpressed in 50-80\% of ovarian tumors MUC16 is used as a tumor marker for monitoring growth and recurrence of epithelial ovarian cancer [176, 177]. Although MUC4 is overexpressed in human ovarian cancer, much less is known about its biology. MUC4 is a large glycoprotein that is aberrantly expressed in $>90 \%$ of malignant ovarian tumors with very low to an undetectable expression in the normal ovary [174]. Recent studies demonstrate a pathologic role of MUC4 in ovarian cancer by mediating epithelial to mesenchymal transition which is involved in metastasis and enhanced tumor aggression [178]. Despite association of MUC4 with pathologic features, there is no association of expression with outcome in ovarian cancer patients [174]. Mucins are naturally recognized by the immune system. For example, some studies have shown the presence of anti-MUC1 antibodies in healthy individuals as well as in ovarian cancer patients and the levels of anti-MUC1 antibodies inversely correlate with ovarian cancer risk factors $[179,180]$.

Mutation of the p53 gene is one the most common single genetic alterations in ovarian cancer [181]. Either loss of wild type p53 function, gain of oncogenic function, or the ability to activate $\mathrm{p} 53$ severely compromises controlled cellular proliferation and growth [182]. As a result of mutation, p53 is overexpressed in nearly $50 \%$ of ovarian cancers. Goodell showed that the presence of p53 antibodies to be an independent predictor of survival. Specifically, the median survival for antibody positive patients was 51 months compared with 24 months for patients without antibodies [59]. Ovarian cancer patients also develop p53-specific T cell memory [183].

Cancer testes antigens (CTAs) are also important in ovarian cancer. Some members of the CTA family that are expressed in ovarian cancer, include BAGE, GAGE, LAGE, MAGE, sperm protein 17 (SP17), NY-ESO-1, AKAP4, and the synovial sarcoma X (SSX) genes [103, 184-189]. Among the CTAs in ovarian cancer, immunity to NY-ESO-1 is best characterized and clinically targeted as described above. CTAs are biologically important antigens. Zhang and colleagues showed that moderate to high expression of MAGE-1 and MAGE-3 in ovarian cancer tissue positively correlated with tumor differentiation and clinical stage [185]. It was found that overexpression of SP17 in ovarian cancer cells results in enhanced migration and chemoresistance [190]. CTAs, due to their restricted expression in the body, tend to be very immunogenic but whether or not they will make good targets for immune mediated rejection remains to be determined [189].

Folate receptor alpha (FRa) is a glycosyl-phosphatidylinositol linked membrane protein overexpressed in many epithelial cancers [191-193]. Expression of FRa in non-mucinous ovarian tumors is increased $\sim 90$ fold in comparison with normal epithelial cells [194]. Like HER-2/neu, FRa is attractive target because its expression is relatively limited to a few tissues, notably the apical surface of kidney tubule epithelium where it is involved in recovery of folate from the urine [195]. Interest in targeting FRa was initially established by Peoples and colleagues who identified several HLA-A2 (MHC class I) peptides derived 
from FRa [196, 197]. Using a CD4+ T cell epitope prediction algorithm in another study, we predicted promiscuous epitopes of FRa [60]. Fourteen peptides were predicted, and it was found that more than $70 \%$ of patients demonstrated immunity to at least one epitope demonstrating natural immune responses to FRa. The FRa appears to be an outstanding tumor rejection antigen as will be discussed below.

Mammaglobin B has also been recently identified as a strongly immunogenic target in ovarian cancer. Mammaglobin B is a small secreted protein belonging to the uteroglobin family and is typically associated with the mammary gland. In a recent study by Tassi, mammaglobin B was found to be highly overexpressed in nearly $50 \%$ of ovarian cancer specimens and high level expression independently correlated with a better outcome [198-200]. Bellone and colleagues [201] subsequently showed that it was highly immunogenic as can generate robust antibody responses and containing $\mathrm{T}$ cell epitopes.

Epithelial cell adhesion molecule (EpCAM) is a type I membrane glycoprotein that is expressed in almost all epithelial cell membranes but not on mesodermal or neural cell membranes [65]. In a retrospective study done by Kobel and colleagues on 500 ovarian cancer patients, EpCAM was highly expressed across all ovarian cancer subtypes [66]. EpCAM is naturally targeted by the immune system but the extent and nature of the immune responses remain undefined [70]. Its expression in ovarian cancer has led to its use as a targeting motif for engineered immune therapies and monoclonal antibody therapy.

Lastly, another target for ovarian cancer is mesothelin which is a $40 \mathrm{kDa}$ cell surface protein that is restrictively expressed on normal mesothelial cells [202]. Although expressed on many cancers, its expression in ovarian cancer is among the highest level, particularly on nonmucinous subtypes [203]. The high level expression in ovarian cancer as well as the fact that it is immunogenic has made it an attractive target antigen [204]. Additionally, studies also have shown that it is potentially a biologically important molecule in ovarian cancer pathogenesis. For example, Cheng and colleagues recently showed that its expression is associated with increased chemoresistance and poor survival [205].

\section{Targeted Monoclonal Antibody Therapies for Treatment of Ovarian Cancer}

Farletuzumab (MORAb-003) is a humanized monoclonal antibody, optimized from the original murine LK26 antibody, which has high affinity for FRa [206]. Preclinical in vivo and in vitro studies have shown that farletuzumab which binds specifically to ovarian cancer cells, has high efficacy in preventing tumor growth with little or no toxicity [207, 208]. A trial by Konner reported that farletuzumab as a single therapy in platinum-resistant ovarian cancer patients was safe and well tolerated at all doses tested and that $35 \%$ of the patients treated with one cycle (four weekly doses) had stable disease and three of these patients received extended therapy showing $3 \%$ to $17 \%$ mean decrease in tumor size. Another trial analyzed farletuzumab as single-agent therapy or in combination with platinum and taxane in platinum-sensitive ovarian cancer patients with first recurrence of disease [209, 210]. In that trial, the group treated with farletuzumab combination therapy showed a $7 \%$ complete response, $63 \%$ partial response and $89 \%$ of the patients achieved normal CA125. Moreover, four patients still remained in remission with median extension of the secondary remission 
being eleven months [211]. Despite these very positive results, the developing company, Eisai Inc., revealed in the first quarter of 2013 via a news release that a double blinded phase III in platinum-sensitive disease failed to achieve the endpoint of improved progression free survival but further analyses are ongoing to determine if subsets of patients experienced benefits.

HER-2/neu antibodies, namely trastuzumab and pertuzumab, have been extensively studied as therapeutics for the small subset of patients with tumors that overexpress HER-2/neu. Trastuzumab (Herceptin) is a humanized monoclonal antibody that targets the HER-2/neu extracellular domain and inhibits HER-2/neu-positive tumor cell proliferation. This antibody is standard of care for patients with HER-2/neu ${ }^{+}$breast cancer [212]. Few clinical trials have been reported on the use of trastuzumab in ovarian cancer. One study done in 41 patients showed that trastuzumab given as single agent therapy demonstrated a low response rate $(\sim 7 \%)$ and a 2-month median progression-free interval [162]. A phase II clinical study looked at the efficacy and tolerance of trastuzumab when combined with paclitaxel and carboplatin in seven patients with taxane/carboplatin resistant ovarian cancer and HER-2/neu overexpression finding that combination treatment elicited a clinical response in three patients with a median PFS of 2.9 months and overall survival of 12.3 months [213]. Another trial done in 33 patients with mucinous ovarian carcinoma showed $~ 18 \%$ HER-2 expression, and of the three patients treated with chemotherapy and trastuzumab, one had complete effective response and another had partial response, suggesting that trastuzumab may be effective for this subset of individuals [214].

Pertuzumab (rhuMAb 2C4, Omnitarg) is a HER-2/neu targeted monoclonal antibody that binds to an epitope distinct from that of trastuzumab, inhibiting heterodimer formation with other HER-family receptors and halting the proliferation of ovarian cancer $[215,216]$. The first clinical study was done by Gordon who showed that as a monotherapy pertuzumab, in recurrent ovarian cancer, demonstrated a $4.3 \%$ partial response rate and stable disease in $6.8 \%$ for six months with a median PFS of 6.6 weeks in patients with recurrent ovarian carcinoma [215]. A study done in platinum-resistant patients showed that the combination therapy of pertuzumab with gemcitabine resulted in a response rate of $13.8 \%$ with 2.9 months PFS as compared with a $4.6 \%$ response rate and PFS of 1.5 months in the placebo group [217]. A randomized study of 152 platinum-sensitive patients evaluated the activity of pertuzumab and carboplatin-based therapy compared with carboplatin therapy alone [218]. In their preliminary report of their study, the investigators demonstrated that pertuzumab with carboplatin was well tolerated, had a 64\% response rate and PFS of 34.1 weeks in comparison with a 52\% response rate and PFS of 31.3 weeks in the single-agent carboplatin group, suggesting some activity [219]. However, in their final report, the team found no evidence that inclusion of pertuzumab into chemotherapy improves either progression-free survival or response to therapy rates [218].

Abagovomab is an anti-idiotype monoclonal antibody whose variable region mirrors CA-125. Abagovomab does not bind directly to CA-125, but it acts as a surrogate antigen able to generate antibody responses against CA-125 protein. In a Phase Ib/II study on 119 patients with advanced ovarian cancer who were resistant to standard therapies, treatment with abagovomab appeared to have led to improved survival time (23.4 months compared to 
4.9 months) in those patients who responded to the vaccination with the generation of an immune response [220, 221]. The vaccine had little side effects and two additional phase I trials were done to determine the best dose, schedule and route of administration, which paved the way to a Phase III double blinded clinical trial [220]. The phase III enrolled 888 women in first remission with a 2:1 ratio. By the final patient visit, the median anti-idiotypic antibody level was a robust $493 \mu \mathrm{g} / \mathrm{ml}$. But, despite the strong immune response, neither recurrence free or overall survival was prolonged and further development of the drug for ovarian cancer was apparently terminated despite impressive early trial data [222]. This pathway is very reminiscent of that of oregovomab, a high affinity monoclonal antibody that binds directly to CA-125. Oregovomab has been tested in various phase II and III clinical trials as both frontline and maintenance therapy [223-225].

Unlike the antibodies described above, Catumaxomab is a trifunctional antibody with bispecificity for EpCAM on tumor cells and CD3 on T cells. Trifunctional antibodies induce a multi-cell complex of tumor cells, $\mathrm{T}$ cells, and accessory immune cells (e.g. macrophages, DCs and NK cells) [226]. This drug has been approved in Europe since 2009 for the treatment of ascites associated with EpCAM-positive cancers. This drug has also been tested in the clinical setting as a new therapeutic strategy for ovarian cancer patients with symptomatic malignant ascites. A clinical study from Burges and colleagues showed good tolerance of patients with recurrent ascites due to ovarian cancer [227]. The trial showed a significant decrease in ascites production in all patients with a decrease in the number of EpCAM+ tumor cells from $540,000 / 10^{6}$ total cells before treatment to $39 / 10^{6}$ following the last infusion. Another trial in patients with malignant ascites due to epithelial cancers (129 ovarian and 129 non-ovarian) assessed the efficacy and safety of Catumaxomab and paracentesis compared with paracentesis alone [228]. This study showed Catumaxomab reduced the ascites volume and the time between paracentesis in both cancer groups but most significantly in the ovarian cancer group along with an overall survival of 110 days compared to 81 days in the control group. Baumann and colleagues recently published results of a phase IIa trial in which 45 patients with platinum-resistant (or refractory) disease were treated with one of two doses of drug given as monotherapy directly intraperitoneally [229]. With only one partial response and seven disease stabilizations, the activity was considered very modest. Despite the modest activity, there are clinical trials underway, at the time of preparation of this review, testing different strategies such as treatment with the antibody prior to initiation of chemotherapy at time of recurrence (either biochemical or RECIST).

Siltuximab (CNTO328), a human-mouse chimeric IL-6 antibody, has been used in multiple clinical trials for a variety of cancers, including ovarian, renal, and prostate [134, 230-233]. In a phase II trial of 18 ovarian cancer patients, one individual had a partial response and 7 had stable disease for a period of time [140]. In another early stage monotherapy trial which included 29 ovarian cancer patients, no objective responses were observed suggesting that ovarian cancer can easily evade the IL-6 blockade [234].

The use of monoclonal antibody-based checkpoint blockade for the treatment of ovarian cancer is also being developed as well targeting CTLA-4 or the PD-1/PD-L1 axis. The antiCTLA-4 antibody widely being tested is ipilimumab. The first indication that this drug may 
be useful came from Hodi and colleagues who enrolled two ovarian cancer patients in an early trial and demonstrated reduction in CA-125 in one patient and stabilization in another [235]. At the time of writing of this review, no other results in ovarian have been published, however, ClinicalTrials.gov (www.clinictrials.gov) lists a phase II study testing the safety and efficacy of ipilimumab monotherapy following completion of chemotherapy in recurrent platinum sensitive ovarian cancer patients with residual disease in the second, third, or fourth line therapy. The safety and preliminary activity of anti-PD-L1 has recently been reported in 17 patients with ovarian cancer. One of 17 had a partial response and 3 patients had disease stabilization for at least 24 weeks [236].

\section{Recent advances in cell based therapies}

Adoptive T cell therapy involves ex vivo activation, expansion, and re-infusion of either natural or engineered antigen-specific T cells [237-240]. The approach has been used successfully for the treatment of melanoma and other cancer, and is envisioned to be useful for ovarian cancer [241]. From a technical and infrastructure standpoint, adoptive T cell therapy remains a challenge. A few clinical trials of adoptive $\mathrm{T}$ cell therapy in ovarian cancer have been reported. The first clinical trial, in patients with recurrent disease, by Kershaw examined the feasibility of infusion of $\mathrm{T}$ cells engineered to express a FRareceptor antibody coupled to the signaling motif of the Fc receptor $\gamma$ chain [242]. While the infusions were found to be safe, no clinical activity was observed, likely due to the observation that the infused $\mathrm{T}$ cells did not persist for long periods of time in large numbers [241] and potentially an inhibitory factor which developed in a half of the patients. In another trial patients were infused with non-modified MUC1-specific Th1 effector T cells [243, 244]. MUC1-specific T cells were derived by repeated stimulation and expansion of leukapheresis-derived cells with the 20mer MUC1 peptide, GSTAPPAHGVTSAPATAPAP. Three doses ranging from $10^{8}$ to $10^{9}$ cells (largely CD4 T cells), were administered intraperitoneally into seven patients. Three patients were discontinued treatment due to local inflammation or obstruction at the intraperitoneal port; in the four remaining patients, treatment was shown to increase systemic MUC1 immune responses, which could have contributed to the long term survival seen in two of the patients. Similarly, in another study, 7 subjects with recurrent ovarian cancer underwent up to 4 cycles with in vitro generated CTLs that were specific for MUC1. The tumor marker CA-125 was non-statistically reduced after the first month of immunotherapy. One subject was free of disease since December 2000 at the time of publication [245].

\section{Therapeutic cancer vaccines}

Therapeutic vaccines are an attractive type of active immunotherapy that offers several advantages such as ease of manufacturing and non-autologous approach. There have been several types of vaccines developed for ovarian cancer such as protein, DNA, viral and peptide vaccines. Only a few recently developed novel vaccines with potential clinical activity are highlighted in this review. Le and colleagues recently reported a novel approach employing a Listeria monocytogenes $(\mathrm{Lm})$ based vaccination. $\mathrm{Lm}$ is a highly pathogenic foodborne microorganism that causes serious central nervous system and gastrointestinal pathologies. The microorganism is unique in that it is an obligate intracellular bacterium that 
specifically infects myeloid cells such as DC and therefore could enhance antigen presentation. Le and colleagues recently used an attenuated Lm vector encoding mesothelin to vaccinate treatment refractory patients with various solid tumors including patients with ovarian cancer [246]. Patients were only given a single dose, the vaccine was well tolerated, and patients generated mesothelin immune responses in about $60 \%$ of immunized individuals. Importantly, although only a phase I trial, $37 \%$ of patients survived $\geq 15$ months. These results are encouraging because the approach is not limited to specific HLA genotypes and could possibly overcome many of the problems, such as inefficient antigen presentation encountered with whole protein approaches.

Peptide-based cancer vaccines are typically short-minimal fragments whose utility is limited to those patients with specific HLA molecules One way to overcome this problem, while avoiding issues related to deficient processing of whole recombinant protein is to use single or pooled synthetic long peptides [247]. This approach was used recently by Sabbatini and colleagues who developed a pool of NY-ESO-1 overlapping peptides [248]. Twenty patients with advanced ovarian cancer in second or third remission were given five challenges with vaccine in Montanide-ISA and poly-ICLC as vaccine adjuvants. Greater than $90 \%$ of patients developed immunity to the peptides and in some cases at very high levels, suggesting that this strategy is very efficient in immunizing against self antigens. It is less clear if the immune responses could easily recognize naturally processed whole protein. Nonetheless, some early indications of improved survival were observed in patients whose tumors demonstrated expression of NY-ESO-1.

While most of the vaccines being tested in the setting of ovarian cancer target the generation of $\mathrm{T}$ cells, the fact that antibody immunity correlates with disease outcomes in patients makes antibody-inducing vaccines a logical option to explore. To that end, Kaumaya determined the activity of a HER-2/neu antibody-inducing chimeric peptide (aa 628-647, and aa 316-339) vaccine with a promiscuous T-cell epitope (aa 280-302) from the measles virus fusion protein (MVF) in patients with metastatic solid tumors including patients with advanced ovarian cancer [249]. This study demonstrated that this vaccine is moderately well tolerated (20\% severe adverse events) and elicits IgG antibodies at all doses. Moreover, of six patients that showed clinical benefit, two were patients with ovarian cancer who had a high antibody response to the vaccine [249].

Overall, the few vaccine trials that have been conducted reveal that patients can mount immunity safely to tumor antigens paving the way for advanced clinical trials designed to test clinical efficacy. Optimism remains that vaccines may be able to, in subsets of patients, eradicate residual tumor to prevent recurrence or disease progression. Indeed, Hernando recently published a case report demonstrating vaccine potency in a single patient with metastatic ovarian cancer [250]. The patient had been previously treated twice with surgical debulking and platinum based therapy. At third recurrence, four months following the last therapy, the patient presented with an axillary lymph node metastasis and a para-aortic mass. At that time, a vaccination regimen with autologous dendritic cells engineered to express FRa was initiated. CT scans before and three months after the last treatment showed a marked, albeit partial, shrinkage in tumor. CA-125 levels which were rising just prior to vaccine, immediately declined to baseline following the first two vaccinations. A follow-up 
CT scan at sixteen months following the start of vaccination showed greater than $50 \%$ regression. Immune monitoring revealed that the patient developed strong FRa-specific $\mathrm{T}$ cell immunity to the vaccine. Remarkably, at eleven months following the last vaccine, CA-125 levels remained at baseline showing that vaccines can induce long-term remission.

\section{Conclusions}

Despite early clinical trials data that immunotherapy approaches may have efficacy, the approaches (mainly monoclonal antibody therapy) that reach phase III clinical trials overwhelmingly fail in ovarian cancer. This is due to at least two reasons. First, early trials fail to define companion predictors that may better inform the design of the intent-to-treat population. As such, trials are typically open to all patients significantly reducing power to detect an impact on the disease. Second and most importantly, treatments are almost done in patients with very advanced refractory disease, a disease state that is characterized by increased plasticity of the tumor cells allowing them to rapidly adapt to hostile microenvironments. One way to solve this problem is to detect ovarian cancer much earlier in the course of disease or develop methods to prevent disease altogether. As discussed, there is significant evidence to suggest that the immune system is involved in the initiation of ovarian cancer, potentially paving the way to preventive strategies such as antiinflammatory drugs and vaccines. Alternatively, there is general agreement in the field that combination approaches could lead to synergism and perhaps greater efficacy in the setting of established disease. A number of strategies have emerged, some of which are being tested clinically. For example, the efficacy of trastuzumab therapy may be improved by combining with agents that boost $\mathrm{T}$ cell immunity. In one study, Zum Buschenfelde found that pretreatment of HER-2/neu ${ }^{+}$ovarian tumor cells with trastuzumab enhanced the cytolytic activity of HER-2/neu-specific T cells against the HER-2/neuoverexpressing tumors in vitro [251]. Although the mechanism is unclear, it is possible that trastuzumab promotes the internalization and degradation of HER-2/neu, resulting in increased presentation of HER-2/neu MHC class I epitopes which may lead to greater activation and expansion of HER-2/neu-specific T cells. A clinical trial of combination trastuzumab and HER-2/neu vaccination in breast cancer was recently reported by Disis and colleagues [252]. Twentytwo patients with HER-2/neu-overexpressing metastatic breast cancer receiving trastuzumab therapy were vaccinated with an HER-2/neu T cell peptide-based vaccine. The patients had either no evidence of disease or stable masses at the time of therapy. The combination was well tolerated. While many patients had pre-existing immunity to HER-2/neu while treated with trastuzumab alone, that immunity could be significantly boosted and maintained with vaccination. Importantly, at a median follow-up of 36 months from the first vaccine, the median overall survival in the study population has not been reached.

Alternatively, the development of checkpoint blockade opens up a range of possibilities. For example, we recently reported on the development of a combination approach incorporating anti-PD-1 antibody and a multi-peptide vaccine [81]. The vaccine was unique and was developed to target the inherent plasticity in breast cancer aimed at generating $\mathrm{T}$ cells against both epithelial tumor cells as well tumor-initiating breast cancer stem cells. We found that combination therapy when given during rapid tumor growth was able to regress $75 \%$ of tumors and prolonged the vaccine-induced progression-free survival period. The 
combination resulting in regressing tumors were infiltrated with increased numbers of $\mathrm{Tc} 1$ and Tc2 CD8 T cells with a memory precursor phenotype. We also observed that combination therapy enhanced the antigen reactivity of tumor-infiltrating CD8 T cells as determined by increase in IFN- $\gamma$, TNF- $\alpha$, IL-2, IL-5, and IL-4 production. Given the recent success of anti-PD-1 monotherapy, our results are encouraging for developing future combination therapies for the treatment of cancer patients. Alternatively, targeted therapeutics, such as small molecule inhibitors, could also work in concert with vaccines. An example is inhibitors of transforming growth factor- $\beta$ (TGF- $\beta$ ), a growth factor with multiple roles in cancer [253, 254]. TGF- $\beta$ promotes tumor progression, invasion, and metastasis by inducing epithelial to mesenchymal transition (EMT), migration, and release of vascular endothelial growth factor [253]. TGF- $\beta$ also directly inhibits cytotoxic actions of tumor-infiltrating CD8 T cells [255]. Thus, an agent that simultaneously blocks immunosuppression and tumor progression may be more effective by providing sufficient time for the immune system to expand and destroy residual tumor burden. Many combinatorial strategies are currently being tested and time will tell whether such mixing will be therapeutically effective.

\section{Acknowledgements}

This work is supported by P50-CA136393 (KLK), a grant from the Marsha Rivkin Foundation and support from the Mayo Graduate School (PL). The authors gratefully acknowledge the expert editorial assistance of Shaundia White of the Vaccine and Gene Therapy Institute of Florida.

\section{References}

1. Siegel R, Naishadham D, Jemal A. Cancer statistics, 2013. A Cancer Journal for Clinicians. 2013; 63(1):11-30. doi:10.3322/caac.21166.

2. Aletti GD, Gallenberg MM, Cliby WA, Jatoi A, Hartmann LC. Current management strategies for ovarian cancer. Mayo Clinic Proceedings. 2007; 82(6):751-770. doi:10.4065/82.6.751. [PubMed: 17550756]

3. Cannistra SA. Cancer of the ovary. The New England Journal of Medicine. 2004; 351(24):25192529. doi:10.1056/NEJMra041842. [PubMed: 15590954]

4. Ozols RF, Bundy BN, Greer BE, Fowler JM, Clarke-Pearson D, Burger RA, et al. Phase III trial of carboplatin and paclitaxel compared with cisplatin and paclitaxel in patients with optimally resected stage III ovarian cancer: a Gynecologic Oncology Group study. Journal of Clinical Oncology. 2003; 21(17):3194-3200. doi:10.1200/JCO.2003.02.153. [PubMed: 12860964]

5. Vaughan S, Coward JI, Bast RC Jr. Berchuck A, Berek JS, Brenton JD, et al. Rethinking ovarian cancer: recommendations for improving outcomes. Nature Reviews Cancer. 2011; 11(10):719-725. doi:10.1038/nrc3144.

6. Merritt MA, Green AC, Nagle CM, Webb PM, S. Australian Cancer; G. Australian Ovarian Cancer Study. Talcum powder, chronic pelvic inflammation and NSAIDs in relation to risk of epithelial ovarian cancer. International Journal of Cancer. 2008; 122(1):170-176. doi:10.1002/ijc.23017.

7. Mahdavi A, Pejovic T, Nezhat F. Induction of ovulation and ovarian cancer: a critical review of the literature. Fertility and Sterility. 2006; 85(4):819-826. doi:10.1016/j.fertnstert.2005.08.061. [PubMed: 16580355]

8. Adami HO, Hsieh CC, Lambe M, Trichopoulos D, Leon D, Persson I, et al. Parity, age at first childbirth, and risk of ovarian cancer. Lancet. 1994; 344(8932):1250-1254. [PubMed: 7967985]

9. Modan B, Hartge P, Hirsh-Yechezkel G, Chetrit A, Lubin F, Beller U, et al. Parity, oral contraceptives, and the risk of ovarian cancer among carriers and noncarriers of a BRCA1 or BRCA2 mutation. The New England Journal of Medicine. 2001; 345(4):235-240. doi:10.1056/ NEJM200107263450401. [PubMed: 11474660] 
10. Collaborative Group on Epidemiological Studies of Ovarian, C. Beral V, Doll R, Hermon C, Peto R, Reeves G. Ovarian cancer and oral contraceptives: collaborative reanalysis of data from 45 epidemiological studies including 23,257 women with ovarian cancer and 87,303 controls. Lancet. 2008; 371(9609):303-314. doi:10.1016/S0140-6736(08)60167-1. [PubMed: 18294997]

11. Narod SA, Risch H, Moslehi R, Dorum A, Neuhausen S, Olsson H, et al. Hereditary Ovarian Cancer Clinical Study Group. Oral contraceptives and the risk of hereditary ovarian cancer. The New England Journal of Medicine. 1998; 339(7):424-428. doi:10.1056/NEJM199808133390702. [PubMed: 9700175]

12. Jordan SJ, Cushing-Haugen KL, Wicklund KG, Doherty JA, Rossing MA. Breast-feeding and risk of epithelial ovarian cancer. Cancer Causes \& Control. 2012; 23(6):919-927. doi:10.1007/ s10552-012-9963-4. [PubMed: 22527170]

13. Jordan SJ, Siskind V, A CG, Whiteman DC, Webb PM. Breastfeeding and risk of epithelial ovarian cancer. Cancer Causes \& Control. 2010; 21(1):109-116. doi:10.1007/s10552-009-9440-x. [PubMed: 19779839]

14. Titus-Ernstoff L, Perez K, Cramer DW, Harlow BL, Baron JA, Greenberg ER. Menstrual and reproductive factors in relation to ovarian cancer risk. British Journal of Cancer. 2001; 84(5):714721. doi:10.1054/bjoc.2000.1596. [PubMed: 11237375]

15. Casagrande JT, Louie EW, Pike MC, Roy S, Ross RK, Henderson BE. "Incessant ovulation" and ovarian cancer. Lancet. 1979; 2(8135):170-173. doi:10.1016/S0140-6736(79)91435-1. [PubMed: 89281]

16. King SM, Hilliard TS, Wu LY, Jaffe RC, Fazleabas AT, Burdette JE. The impact of ovulation on fallopian tube epithelial cells: evaluating three hypotheses connecting ovulation and serous ovarian cancer. Endocrine Related Cancer. 2011; 18(5):627-642. doi:10.1530/ERC-11-0107. [PubMed: 21813729]

17. Wehner AP. Biological effects of cosmetic talc. Food and Chemical Toxicology. 1994; 32(12): 1173-1184. [PubMed: 7813991]

18. Mills PK, Riordan DG, Cress RD, Young HA. Perineal talc exposure and epithelial ovarian cancer risk in the Central Valley of California. International Journal of Cancer. 2004; 112(3):458-464. doi:10.1002/ijc.20434.

19. Rosenblatt KA, Weiss NS, Cushing-Haugen KL, Wicklund KG, Rossing MA. Genital powder exposure and the risk of epithelial ovarian cancer. Cancer Causes \& Control. 2011; 22(5):737-742. doi:10.1007/s10552-011-9746-3. [PubMed: 21516319]

20. Wu AH, Pearce CL, Tseng CC, Templeman C, Pike MC. Markers of inflammation and risk of ovarian cancer in Los Angeles County. International Journal of Cancer. 2009; 124(6):1409-1415. doi:10.1002/ijc.24091.

21. Huncharek M, Geschwind JF, Kupelnick B. Perineal application of cosmetic talc and risk of invasive epithelial ovarian cancer: a meta-analysis of 11,933 subjects from sixteen observational studies. Anticancer research. 23(2C). 2003:1955-1960. [PubMed: 12820486]

22. Huncharek M, Muscat J. Perineal talc use and ovarian cancer risk: a case study of scientific standards in environmental epidemiology. European Journal of Cancer Prevention. 2011; 20(6): 501-507. doi:10.1097/CEJ.0b013e3283476242. [PubMed: 21712717]

23. Pearce CL, Templeman C, Rossing MA, Lee A, Near AM, Webb PM, et al. Association between endometriosis and risk of histological subtypes of ovarian cancer: a pooled analysis of case-control studies. The Lancet Oncology. 2012; 13(4):385-394. doi:10.1016/S1470-2045(11)70404-1. [PubMed: 22361336]

24. D'Hooghe TM, Debrock S. Endometriosis, retrograde menstruation and peritoneal inflammation in women and in baboons. Human reproduction update. 2002; 8(1):84-88. [PubMed: 11866244]

25. Risch HA, Howe GR. Pelvic inflammatory disease and the risk of epithelial ovarian cancer. Cancer Epidemiology, Biomarkers \& Prevention. 1995; 4(5):447-451.

26. Lin HW, Tu YY, Lin SY, Su WJ, Lin WL, Lin WZ, et al. Risk of ovarian cancer in women with pelvic inflammatory disease: a population-based study. The Lancet Oncology. 2011; 12(9):900904. doi:10.1016/S1470-2045(11)70165-6. [PubMed: 21835693] 
27. Bonovas S, Filioussi K, Sitaras NM. Do nonsteroidal anti-inflammatory drugs affect the risk of developing ovarian cancer? A meta-analysis. British Journal of Clinical Pharmacology. 2005; 60(2):194-203. doi:10.1111/j.1365-2125.2005.02386.x. [PubMed: 16042673]

28. Wang Z, Moult J. SNPs, protein structure, and disease. Human Mutation. 2001; 17(4):263-270. doi:10.1002/humu.22. [PubMed: 11295823]

29. Bolton KL, Tyrer J, Song H, Ramus SJ, Notaridou M, Jones C, et al. Common variants at 19p13 are associated with susceptibility to ovarian cancer. Nature Genetics. 2010; 42(10):880-884. doi: 10.1038/ng.666. [PubMed: 20852633]

30. Goode EL, Chenevix-Trench G, Song H, Ramus SJ, Notaridou M, Lawrenson K, et al. A genomewide association study identifies susceptibility loci for ovarian cancer at $2 \mathrm{q} 31$ and $8 \mathrm{q} 24$. Nature Genetics. 2010; 42(10):874-879. doi:10.1038/ng.668. [PubMed: 20852632]

31. Song H, Ramus SJ, Tyrer J, Bolton KL, Gentry-Maharaj A, Wozniak E, et al. A genome-wide association study identifies a new ovarian cancer susceptibility locus on 9p22.2. Nature Genetics. 2009; 41(9):996-1000. doi:10.1038/ng.424. [PubMed: 19648919]

32. Fan Y, Yu W, Ye P, Wang H, Wang Z, Meng Q, et al. NFKB1 insertion/deletion promoter polymorphism increases the risk of advanced ovarian cancer in a Chinese population. DNA and Cell Biology. 2011; 30(4):241-245. doi:10.1089/dna.20doi:10.1107. [PubMed: 21138333]

33. Lubinski J, Huzarski T, Kurzawski G, Suchy J, Masojc B, Mierzejewski M, et al. The 3020insC Allele of NOD2 Predisposes to Cancers of Multiple Organs. Hereditary Cancer in Clinical Practice. 2005; 3(2):59-63. doi:10.1186/1897-4287-3-2-59. [PubMed: 20223031]

34. White KL, Vierkant RA, Phelan CM, Fridley BL, Anderson S, Knutson KL, et al. Polymorphisms in NF-kappaB inhibitors and risk of epithelial ovarian cancer. BMC Cancer. 2009; 9:170. doi: 10.1186/1471-2407-9-170. [PubMed: 19500386]

35. Ma X, Zhang J, Liu S, Huang Y, Chen B, Wang D. Polymorphisms in the CASP8 gene and the risk of epithelial ovarian cancer. Gynecologic Oncology. 2011; 122(3):554-559. doi:10.1016/j.ygyno. 2011.05.031. [PubMed: 21714991]

36. Engel C, Versmold B, Wappenschmidt B, Simard J, Easton DF, Peock S, et al. Association of the variants CASP8 D302H and CASP10 V410I with breast and ovarian cancer risk in BRCA1 and BRCA2 mutation carriers. Cancer Epidemiology, Biomarkers \& Prevention. 2010; 19(11):28592868. doi:10.1158/1055-9965.EPI-10-0517.

37. Nevadunsky NS, Korneeva I, Caputo T, Witkin SS. Mannose-binding lectin codon 54 genetic polymorphism and vaginal protein levels in women with gynecologic malignancies. European Journal of Obstetrics, Gynecology, and Reproductive Biology. 2012; 163(2):216-218. doi: 10.1016/j.ejogrb.2012.04.020.

38. Lurie G, Terry KL, Wilkens LR, Thompson PJ, McDuffie KE, Carney ME, et al. Pooled analysis of the association of PTGS2 rs5275 polymorphism and NSAID use with invasive ovarian carcinoma risk. Cancer Causes \& Control. 2010; 21(10):1731-1741. doi:10.1007/ s10552-010-9602-x. [PubMed: 20559705]

39. White KL, Schildkraut JM, Palmieri RT, Iversen ES Jr. Berchuck A, Vierkant RA, et al. Ovarian cancer risk associated with inherited inflammation-related variants. Cancer Research. 2012; 72(5): 1064-1069. doi:10.1158/0008-5472.CAN-11-3512. [PubMed: 22282663]

40. Liang D, Meyer L, Chang DW, Lin J, Pu X, Ye Y, et al. Genetic variants in MicroRNA biosynthesis pathways and binding sites modify ovarian cancer risk, survival, and treatment response. Cancer Research. 2010; 70(23):9765-9776. doi:10.1158/0008-5472.CAN-10-0130. [PubMed: 21118967]

41. Charbonneau B, Block MS, Bamlet WR, Vierkant RA, Kalli KR, Fogarty Z, et al. Risk of ovarian cancer and the NF-kappaB pathway: genetic association with IL1A and TNFSFdoi:10. Cancer Research. 2014; 74(3):852-861. doi:10.1158/0008-5472.CAN-13-1051. [PubMed: 24272484]

42. Palmieri RT, Wilson MA, Iversen ES, Clyde MA, Calingaert B, Moorman PG, et al. Polymorphism in the IL18 gene and epithelial ovarian cancer in non-Hispanic white women. Cancer Epidemiology, Biomarkers \& Prevention. 2008; 17(12):3567-3572. doi: 10.1158/1055-9965.EPI-08-0548. 
43. Gabay C, Kushner I. Acute-phase proteins and other systemic responses to inflammation. The New England Journal of Medicine. 1999; 340(6):448-454. doi:10.1056/NEJM199902113400607. [PubMed: 9971870]

44. Ridker PM. Inflammatory biomarkers and risks of myocardial infarction, stroke, diabetes, and total mortality: implications for longevity. Nutrition Reviews. 2007; 65(12):S253-259. Pt 2. [PubMed: 18240558]

45. Toriola AT, Grankvist K, Agborsangaya CB, Lukanova A, Lehtinen M, Surcel HM. Changes in pre-diagnostic serum C-reactive protein concentrations and ovarian cancer risk: a longitudinal study. Annals of Oncology. 2011; 22(8):1916-1921. doi:10.1093/annonc/mdq694. [PubMed: 21292643]

46. Lundin E, Dossus L, Clendenen T, Krogh V, Grankvist K, Wulff M, et al. C-reactive protein and ovarian cancer: a prospective study nested in three cohorts (Sweden, USA, Italy). Cancer Causes \& Control. 2009; 20(7):1151-1159. doi:10.1007/s10552-009-9330-2. [PubMed: 19301134]

47. Clendenen TV, Lundin E, Zeleniuch-Jacquotte A, Koenig KL, Berrino F, Lukanova A, et al. Circulating inflammation markers and risk of epithelial ovarian cancer. Cancer Epidemiology, Biomarkers \& Prevention. 2011; 20(5):799-8. doi:10. doi:10.1158/1055-9965.EPI-10-1180.

48. Grivennikov SI, Greten FR, Karin M. Immunity, inflammation, and cancer. Cell. 2010; 140(6): 883-899. doi:10.1016/j.cell.20doi:10.01.025. [PubMed: 20303878]

49. Haskill S, Becker S, Fowler W, Walton L. Mononuclear-cell infiltration in ovarian cancer. I. Inflammatory-cell infiltrates from tumour and ascites material. British Journal of Cancer. 1982; 45(5):728-736. [PubMed: 6979349]

50. Zhang L, Conejo-Garcia JR, Katsaros D, Gimotty PA, Massobrio M, Regnani G, et al. Intratumoral T cells, recurrence, and survival in epithelial ovarian cancer. The New England Journal of Medicine. 2003; 348(3):203-213. doi:10.1056/NEJMoa020177. [PubMed: 12529460]

51. Sato E, Olson SH, Ahn J, Bundy B, Nishikawa H, Qian F, et al. Intraepithelial CD8+ tumorinfiltrating lymphocytes and a high $\mathrm{CD} 8+$ /regulatory $\mathrm{T}$ cell ratio are associated with favorable prognosis in ovarian cancer. Proceedings of the National Academy of Sciences of the United States of America. 2005; 102(51):18538-18543. doi:10.1073/pnas.0509182102. [PubMed: 16344461]

52. Leffers N, Gooden MJ, de Jong RA, Hoogeboom BN, ten Hoor KA, Hollema H, et al. Prognostic significance of tumor-infiltrating T-lymphocytes in primary and metastatic lesions of advanced stage ovarian cancer. Cancer Immunology, Immunotherapy. 2009; 58(3):449-459. doi:10.1007/ s00262-008-0583-5. [PubMed: 18791714]

53. Callahan MJ, Nagymanyoki Z, Bonome T, Johnson ME, Litkouhi B, Sullivan EH, et al. Increased HLA-DMB expression in the tumor epithelium is associated with increased CTL infiltration and improved prognosis in advanced-stage serous ovarian cancer. Clinical Cancer Research. 2008; 14(23):7667-7673. doi:10.1158/1078-0432.CCR-08-0479. [PubMed: 19047092]

54. Leffers N, Fehrmann RS, Gooden MJ, Schulze UR, Ten Hoor KA, Hollema H, et al. Identification of genes and pathways associated with cytotoxic $\mathrm{T}$ lymphocyte infiltration of serous ovarian cancer. British Journal of Cancer. 2010; 103(5):685-692. doi:10.1038/sj.bjc.6605820. [PubMed: 20664601]

55. Milne K, Kobel M, Kalloger SE, Barnes RO, Gao D, Gilks CB, et al. Systematic analysis of immune infiltrates in high-grade serous ovarian cancer reveals CD20, FoxP3 and TIA-1 as positive prognostic factors. PloS one. 2009; 4(7):e6412. doi:10.1371/journal.pone.0006412. [PubMed: 19641607]

56. Le Page C, Marineau A, Bonza PK, Rahimi K, Cyr L, Labouba I, et al. BTN3A2 expression in epithelial ovarian cancer is associated with higher tumor infiltrating $\mathrm{T}$ cells and a better prognosis. PloS One. 2012; 7(6):e38541. doi:10.1371/journal.pone.0038541. [PubMed: 22685580]

57. Kryczek I, Banerjee M, Cheng P, Vatan L, Szeliga W, Wei S, et al. Phenotype, distribution, generation, and functional and clinical relevance of Th17 cells in the human tumor environments. Blood. 2009; 114(6):1141-1149. doi:10.1182/blood-2009-03-208249. [PubMed: 19470694]

58. Cua DJ, Tato CM. Innate IL-17-producing cells: the sentinels of the immune system. Nature Reviews Immunology. 2010; 10(7):479-489. doi:10.1038/nri2800. 
59. Goodell V, Salazar LG, Urban N, Drescher CW, Gray H, Swensen RE, et al. Antibody immunity to the p53 oncogenic protein is a prognostic indicator in ovarian cancer. Journal of Clinical Oncology. 2006; 24(5):762-768. doi:10.1200/JCO.2005.03.2813. [PubMed: 16391298]

60. Knutson KL, Krco CJ, Erskine CL, Goodman K, Kelemen LE, Wettstein PJ, et al. T-cell immunity to the folate receptor alpha is prevalent in women with breast or ovarian cancer. Journal ofClinical Oncology. 2006; 24(26):4254-4261. doi:10.1200/JCO.2006.05.9311.

61. Tchabo NE, Mhawech-Fauceglia P, Caballero OL, Villella J, Beck AF, Miliotto AJ, et al. Expression and serum immunoreactivity of developmentally restricted differentiation antigens in epithelial ovarian cancer. Cancer Immunity. 2009; 9:6. [PubMed: 19705800]

62. Dong HP, Elstrand MB, Holth A, Silins I, Berner A, Trope CG, et al. NK- and B-cell infiltration correlates with worse outcome in metastatic ovarian carcinoma. American Journal of Clinical Pathology. 2006; 125(3):451-458. [PubMed: 16613351]

63. Nielsen JS, Sahota RA, Milne K, Kost SE, Nesslinger NJ, Watson PH, et al. CD20+ tumorinfiltrating lymphocytes have an atypical CD27-memory phenotype and together with CD8+ T cells promote favorable prognosis in ovarian cancer. Clinical Cancer Research. 2012; 18(12): 3281-3292. doi:10.1158/1078-0432.CCR-12-0234. [PubMed: 22553348]

64. Perussia B, Chen Y, Loza MJ. Peripheral NK cell phenotypes: multiple changing of faces of an adapting, developing cell. Molecular Immunology. 2005; 42(4):385-395. doi:10.1016/j.molimm. 2004.07.017. [PubMed: 15607789]

65. Gonzalez S, Lopez-Soto A, Suarez-Alvarez B, Lopez-Vazquez A, Lopez-Larrea C. NKG2D ligands: key targets of the immune response. Trends in Immunology. 2008; 29(8):397-403. doi: 10.1016/j.it.2008.04.007. [PubMed: 18602338]

66. Lopez-Larrea C, Suarez-Alvarez B, Lopez-Soto A, Lopez-Vazquez A, Gonzalez S. The NKG2D receptor: sensing stressed cells. Trends in Molecular Medicine. 2008; 14(4):179-189. doi:10.1016/ j.molmed.2008.02.004. [PubMed: 18353724]

67. Li K, Mandai M, Hamanishi J, Matsumura N, Suzuki A, Yagi H, et al. Clinical significance of the NKG2D ligands, MICA/B and ULBP2 in ovarian cancer: high expression of ULBP2 is an indicator of poor prognosis. Cancer Immunology, Immunotherapy. 2009; 58(5):641-652. doi: 10.1007/s00262-008-0585-3. [PubMed: 18791713]

68. Knutson KL, Disis ML, Salazar LG. CD4 regulatory T cells in human cancer pathogenesis. Cancer Immunology, Immunotherapy. 2007; 56(3):271-285. doi:10.1007/s00262-006-0194-y. [PubMed: 16819631]

69. Bluestone JA, Abbas AK. Natural versus adaptive regulatory T cells. Nature Reviews Immunology. 2003; 3(3):253-257. doi:10.1038/nri1032.

70. Meloni F, Morosini M, Solari N, Passadore I, Nascimbene C, Novo M, et al. Foxp3 expressing $\mathrm{CD} 4+\mathrm{CD} 25+$ and CD8+CD28-T regulatory cells in the peripheral blood of patients with lung cancer and pleural mesothelioma. Human Immunology. 2006; 67(1-2):1-12. doi:10.1016/ j.humimm.2005.11.005. [PubMed: 16698419]

71. Audia S, Nicolas A, Cathelin D, Larmonier N, Ferrand C, Foucher P, et al. Increase of CD4+ $\mathrm{CD} 25+$ regulatory $\mathrm{T}$ cells in the peripheral blood of patients with metastatic carcinoma: a Phase I clinical trial using cyclophosphamide and immunotherapy to eliminate CD4+ CD25+ T lymphocytes. Clinical and Experimental Immunology. 2007; 150(3):523-530. doi:10.1111/j. 1365-2249.2007.03521.x. [PubMed: 17956583]

72. Li X, Ye DF, Xie X, Chen HZ, Lu WG. Proportion of CD4+CD25+ regulatory T cell is increased in the patients with ovarian carcinoma. Cancer Investigation. 2005; 23(5):399-403. [PubMed: 16193639]

73. Preston CC, Maurer MJ, Oberg AL, Visscher DW, Kalli KR, Hartmann LC, et al. The ratios of CD8+ T cells to CD4+CD25+ FOXP3+ and FOXP3-T cells correlate with poor clinical outcome in human serous ovarian cancer. PloS One. 2013; 8(11):e80063. doi:10.1371/journal.pone. 0080063. [PubMed: 24244610]

74. Curiel TJ, Coukos G, Zou L, Alvarez X, Cheng P, Mottram P, et al. Specific recruitment of regulatory $\mathrm{T}$ cells in ovarian carcinoma fosters immune privilege and predicts reduced survival. Nature Medicine. 2004; 10(9):942-949. doi:10.1038/nm1093. 
75. Wolf D, Wolf AM, Rumpold H, Fiegl H, Zeimet AG, Muller-Holzner E, et al. The expression of the regulatory $\mathrm{T}$ cell-specific forkhead box transcription factor FoxP3 is associated with poor prognosis in ovarian cancer. Clinical Cancer Research. 2005; 11(23):8326-8331. doi: 10.1158/1078-0432.CCR-05-1244. [PubMed: 16322292]

76. Murray PJ, Wynn TA. Protective and pathogenic functions of macrophage subsets. Nature Reviews Immunology. 2011; 11(11):723-737. doi:10.1038/nri3073.

77. Hagemann T, Wilson J, Burke F, Kulbe H, Li NF, Pluddemann A, et al. Ovarian cancer cells polarize macrophages toward a tumor-associated phenotype. Journal of Immunology. 2006; 176(8):5023-5032. 176/8/5023 [pii].

78. Ko SY, Ladanyi A, Lengyel E, Naora H. Expression of the homeobox gene HOXA9 in ovarian cancer induces peritoneal macrophages to acquire an M2 tumorpromoting phenotype. The American Journal of Pathology. 2014; 184(1):271-281. doi:10.1016/j.ajpath.2013.09.017. [PubMed: 24332016]

79. Shah CA, Allison KH, Garcia RL, Gray HJ, Goff BA, Swisher EM. Intratumoral T cells, tumorassociated macrophages, and regulatory T cells: association with p53 mutations, circulating tumor DNA and survival in women with ovarian cancer. Gynecologic Oncology. 2008; 109(2):215-219. doi:10.1016/j.ygyno.2008.01.0doi:10. [PubMed: 18314181]

80. Lan C, Huang X, Lin S, Huang H, Cai Q, Wan T, et al. Expression of M2-polarized macrophages is associated with poor prognosis for advanced epithelial ovarian cancer. Technology in Cancer Research \& Treatment. 2013; 12(3):259-267. doi:10.7785/tcrt.2012.500312. [PubMed: 23289476]

81. Karyampudi L, Lamichhane P, Scheid AD, Kalli KR, Shreeder B, Krempski JW, et al. Accumulation of Memory Precursor CD8 T Cells in Regressing Tumors following Combination Therapy with Vaccine and Anti-PD-1 Antibody. Cancer Research. 2014; 74(11):2974-2985. doi: 10.1158/0008-5472.CAN-13-2564. [PubMed: 24728077]

82. Fricke I, Gabrilovich DI. Dendritic cells and tumor microenvironment: a dangerous liaison. Immunological Investigations. 35(3-4). 2006:459-483. doi:10.1080/08820130600803429. [PubMed: 16916762]

83. Chen F, Hou M, Ye F, Lv W, Xie X. Ovarian cancer cells induce peripheral mature dendritic cells to differentiate into macrophagelike cells in vitro. International Journal of Gynecological Cancer. 2009; 19(9):1487-1493. doi:10.1111/IGC.0b013e3181bb70c6. [PubMed: 19955923]

84. Krempski J, Karyampudi L, Behrens MD, Erskine CL, Hartmann L, Dong H, et al. Tumorinfiltrating programmed death receptor-1+ dendritic cells mediate immune suppression in ovarian cancer. Journal of Immunology. 2011; 186(12):6905-6913. doi:10.4049/jimmunol.1100274.

85. Karyampudi L, Lamichhane P, Schied AD, Kalli KR, Schreeder B, Krempski JW, et al. Accumulation of memory precursor CD8 T cells in regressing tumor following combination therapy with vaccine and anti-PD-1 antibody. 2014 (In Press/Online Ahead of Print).

86. Schmid MC, Varner JA. Myeloid cells in the tumor microenvironment: modulation of tumor angiogenesis and tumor inflammation. Journal of Oncology. 2010; 2010:201026. doi: 10.1155/2010/201026. [PubMed: 20490273]

87. Ostrand-Rosenberg S. Myeloid-derived suppressor cells: more mechanisms for inhibiting antitumor immunity. Cancer Immunology, Immunotherapy. 2010; 59(10):1593-1600. doi: 10.1007/s00262-010-0855-8. [PubMed: 20414655]

88. Kerbel RS. Tumor angiogenesis. The New England Journal of Medicine. 2008; 358(19):20392049. doi:10.1056/NEJMra0706596. [PubMed: 18463380]

89. Zou W, Machelon V, Coulomb-L'Hermin A, Borvak J, Nome F, Isaeva T, et al. Stromal-derived factor-1 in human tumors recruits and alters the function of plasmacytoid precursor dendritic cells. Nature Medicine. 2001; 7(12):1339-1346. doi:10.1038/nm1201-1339.

90. Wei S, Kryczek I, Zou L, Daniel B, Cheng P, Mottram P, et al. Plasmacytoid dendritic cells induce CD8+ regulatory T cells in human ovarian carcinoma. Cancer Research. 2005; 65(12):5020-5026. doi:10.1158/0008-5472.CAN-04-4043. [PubMed: 15958543]

91. Huarte E, Cubillos-Ruiz JR, Nesbeth YC, Scarlett UK, Martinez DG, Buckanovich RJ, et al. Depletion of dendritic cells delays ovarian cancer progression by boosting antitumor immunity. Cancer Research. 2008; 68(18):7684-7691. doi:10.1158/0008-5472.CAN-08-1167. [PubMed: 18768667] 
92. Gabrilovich DI, Nagaraj S. Myeloid-derived suppressor cells as regulators of the immune system. Nature Reviews Immunology. 2009; 9(3):162-174. doi:10.1038/nri2506.

93. Movahedi K, Guilliams M, Van den Bossche J, Van den Bergh R, Gysemans C, Beschin A, et al. Identification of discrete tumor-induced myeloid-derived suppressor cell subpopulations with distinct T cell-suppressive activity. Blood. 2008; 111(8):4233-4244. doi:10.1182/ blood-2007-07-099226. [PubMed: 18272812]

94. Youn JI, Nagaraj S, Collazo M, Gabrilovich DI. Subsets of myeloid-derived suppressor cells in tumor-bearing mice. Journal of Immunology. 2008; 181(8):5791-5802. 181/8/5791 [pii].

95. Serafini P, Borrello I, Bronte V. Myeloid suppressor cells in cancer: recruitment, phenotype, properties, and mechanisms of immune suppression. Seminars in Cancer Biology. 2006; 16(1):5365. doi:10.1016/j.semcancer.2005.07.005. [PubMed: 16168663]

96. Yang R, Cai Z, Zhang Y, Yutzy W.H.t. Roby KF, Roden RB. CD80 in immune suppression by mouse ovarian carcinoma-associated Gr-1+CD11b+ myeloid cells. Cancer Research. 2006; 66(13):6807-6815. doi:10.1158/0008-5472.CAN-05-3755. [PubMed: 16818658]

97. Hamanishi J, Mandai M, Iwasaki M, Okazaki T, Tanaka Y, Yamaguchi K, et al. Programmed cell death 1 ligand 1 and tumor-infiltrating CD8+ T lymphocytes are prognostic factors of human ovarian cancer. Proceedings of the National Academy of Sciences of the United States of America. 2007; 104(9):3360-3365. doi:10.1073/pnas.0611533104. [PubMed: 17360651]

98. Ghebeh H, Mohammed S, Al-Omair A, Qattan A, Lehe C, Al-Qudaihi G, et al. The B7-H1 (PDL1) T lymphocyte-inhibitory molecule is expressed in breast cancer patients with infiltrating ductal carcinoma: correlation with important high-risk prognostic factors. Neoplasia. 2006; 8(3): 190-198. doi:10.1593/neo.05733. [PubMed: 16611412]

99. Karim R, Jordanova ES, Piersma SJ, Kenter GG, Chen L, Boer JM, et al. Tumor-expressed B7-H1 and B7-DC in relation to PD-1+ T-cell infiltration and survival of patients with cervical carcinoma. Clinical Cancer Research. 2009; 15(20):6341-6347. doi: 10.1158/1078-0432.CCR-09-1652. [PubMed: 19825956]

100. Keir ME, Butte MJ, Freeman GJ, Sharpe AH. PD-1 and its ligands in tolerance and immunity. Annual Review of Immunology. 26. 2008:677-704. doi:10.1146/annurev.immunol. 26.021607.090331.

101. Keir ME, Francisco LM, Sharpe AH. PD-1 and its ligands in T-cell immunity. Current Opinion in Immunology. 2007; 19(3):309-314. doi:10.1016/j.coi.2007.04.012. [PubMed: 17433872]

102. Keir ME, Liang SC, Guleria I, Latchman YE, Qipo A, Albacker LA, et al. Tissue expression of PD-L1 mediates peripheral T cell tolerance. The Journal of Experimental Medicine. 2006; 203(4):883-895. doi:10.1084/jem.20051776. [PubMed: 16606670]

103. Matsuzaki J, Gnjatic S, Mhawech-Fauceglia P, Beck A, Miller A, Tsuji T, et al. Tumorinfiltrating NY-ESO-1-specific CD8+ T cells are negatively regulated by LAG-3 and PD-1 in human ovarian cancer. Proceedings of the National Academy of Sciences of the United States of America. 2010; 107(17):7875-7880. doi:10.1073/pnas.1003345107. [PubMed: 20385810]

104. Gubbels JA, Belisle J, Onda M, Rancourt C, Migneault M, Ho M, et al. Mesothelin-MUC16 binding is a high affinity, $\mathrm{N}$-glycan dependent interaction that facilitates peritoneal metastasis of ovarian tumors. Molecular Cancer. 2006; 5(1):50. doi:10.1186/1476-4598-5-50. [PubMed: 17067392]

105. Patankar MS, Jing Y, Morrison JC, Belisle JA, Lattanzio FA, Deng Y, et al. Potent suppression of natural killer cell response mediated by the ovarian tumor marker CA125. Gynecologic Oncology. 2005; 99(3):704-713. doi:10.1016/j.ygyno.2005.07.030. [PubMed: 16126266]

106. Gubbels JA, Felder M, Horibata S, Belisle JA, Kapur A, Holden H, et al. MUC16 provides immune protection by inhibiting synapse formation between NK and ovarian tumor cells. Molecular Cancer. 2010; 9:11. doi:10.1186/1476-4598-9-11. [PubMed: 20089172]

107. Belisle JA, Horibata S, Jennifer GA, Petrie S, Kapur A, Andre S, et al. Identification of Siglec-9 as the receptor for MUC16 on human NK cells, B cells, and monocytes. Molecular Cancer. 2010; 9:118. doi:10.1186/1476-4598-9-118. [PubMed: 20497550]

108. Krockenberger M, Dombrowski Y, Weidler C, Ossadnik M, Honig A, Hausler S, et al. Macrophage migration inhibitory factor contributes to the immune escape of ovarian cancer by down-regulating NKG2D. Journal of Immunology. 2008; 180(11):7338-7348. 
109. Uyttenhove C, Pilotte L, Theate I, Stroobant V, Colau D, Parmentier N, et al. Evidence for a tumoral immune resistance mechanism based on tryptophan degradation by indoleamine 2,3dioxygenase. Nature Medicine. 2003; 9(10):1269-1274. doi:10.1038/nm934.

110. Munn DH. Indoleamine 2,3-dioxygenase, tumor-induced tolerance and counter-regulation. Current Opinion in Immunology. 2006; 18(2):220-225. doi:10.1016/j.coi.2006.01.002. [PubMed: 16460921]

111. Terness P, Bauer TM, Rose L, Dufter C, Watzlik A, Simon H, et al. Inhibition of allogeneic T cell proliferation by indoleamine 2,3-dioxygenase-expressing dendritic cells: mediation of suppression by tryptophan metabolites. The Journal of Experimental Medicine. 2002; 196(4): 447-457. [PubMed: 12186837]

112. Munn DH, Sharma MD, Baban B, Harding HP, Zhang Y, Ron D, et al. GCN2 kinase in T cells mediates proliferative arrest and anergy induction in response to indoleamine 2,3-dioxygenase. Immunity. 2005; 22(5):633-642. doi:10.1016/j.immuni.2005.03.013. [PubMed: 15894280]

113. Della Chiesa M, Carlomagno S, Frumento G, Balsamo M, Cantoni C, Conte R, et al. The tryptophan catabolite L-kynurenine inhibits the surface expression of NKp46- and NKG2Dactivating receptors and regulates NK-cell function. Blood. 2006; 108(13):4118-4125. doi: 10.1182/blood-2006-03-006700. [PubMed: 16902152]

114. Chiesa S, Mingueneau M, Fuseri N, Malissen B, Raulet DH, Malissen M, et al. Multiplicity and plasticity of natural killer cell signaling pathways. Blood. 2006; 107(6):2364-2372. doi:10.1182/ blood-2005-08-3504. [PubMed: 16291591]

115. Frumento G, Rotondo R, Tonetti M, Damonte G, Benatti U, Ferrara GB. Tryptophan-derived catabolites are responsible for inhibition of $\mathrm{T}$ and natural killer cell proliferation induced by indoleamine 2,3-dioxygenase. The Journal of Experimental Medicine. 2002; 196(4):459-468. [PubMed: 12186838]

116. Baban B, Chandler PR, Sharma MD, Pihkala J, Koni PA, Munn DH, et al. IDO activates regulatory $\mathrm{T}$ cells and blocks their conversion into Th17-like T cells. Journal of Immunology. 2009; 183(4):2475-2483. doi:10.4049/jimmunol.0900986.

117. Fallarino F, Grohmann U, You S, McGrath BC, Cavener DR, Vacca C, et al. The combined effects of tryptophan starvation and tryptophan catabolites down-regulate T cell receptor zetachain and induce a regulatory phenotype in naive T cells. Journal of Immunology. 2006; 176(11): 6752-6761.

118. Hill M, Tanguy-Royer S, Royer P, Chauveau C, Asghar K, Tesson L, et al. IDO expands human CD4+CD25high regulatory $\mathrm{T}$ cells by promoting maturation of LPS-treated dendritic cells. European Journal of Immunology. 2007; 37(11):3054-3062. doi:10.1002/eji.200636704. [PubMed: 17948274]

119. Inaba T, Ino K, Kajiyama H, Yamamoto E, Shibata K, Nawa A, et al. Role of the immunosuppressive enzyme indoleamine 2,3-dioxygenase in the progression of ovarian carcinoma. Gynecologic Oncology. 2009; 115(2):185-192. doi:10.1016/j.ygyno.2009.07.015. [PubMed: 19665763]

120. Okamoto A, Nikaido T, Ochiai K, Takakura S, Saito M, Aoki Y, et al. Indoleamine 2,3dioxygenase serves as a marker of poor prognosis in gene expression profiles of serous ovarian cancer cells. Clinical Cancer Research. 2005; 11(16):6030-6039. doi: 10.1158/1078-0432.CCR-04-2671. [PubMed: 16115948]

121. Takao M, Okamoto A, Nikaido T, Urashima M, Takakura S, Saito M, et al. Increased synthesis of indoleamine-2,3-dioxygenase protein is positively associated with impaired survival in patients with serous-type, but not with other types of, ovarian cancer. Oncology Reports. 2007; 17(6): 1333-1339. [PubMed: 17487387]

122. Zheng X, Koropatnick J, Li M, Zhang X, Ling F, Ren X, et al. Reinstalling Antitumor Immunity by Inhibiting Tumor-Derived Immunosuppressive Molecule IDO through RNA Interference. Journal of Immunology. 2006; 177(8):5639-5646.

123. Zamanakou M, Germenis AE, Karanikas V. Tumor immune escape mediated by indoleamine 2,3dioxygenase. Immunology Letters. 2007; 111(2):69-75. doi:10.1016/j.imlet.2007.06.001. [PubMed: 17644189]

124. Lob S, Konigsrainer A, Zieker D, Brucher BL, Rammensee HG, Opelz G, et al. IDO1 and IDO2 are expressed in human tumors: levo-but not dextro-1-methyl tryptophan inhibits tryptophan 
catabolism. Cancer Immunology, Immunotherapy. 2009; 58(1):153-157. doi:10.1007/ s00262-008-0513-6. [PubMed: 18418598]

125. Liu X, Shin N, Koblish HK, Yang G, Wang Q, Wang K, et al. Selective inhibition of IDO1 effectively regulates mediators of antitumor immunity. Blood. 2010; 115(17):3520-3530. doi: 10.1182/blood-2009-09-246124. [PubMed: 20197554]

126. Koblish HK, Hansbury MJ, Bowman KJ, Yang G, Neilan CL, Haley PJ, et al. Hydroxyamidine inhibitors of indoleamine-2,3-dioxygenase potently suppress systemic tryptophan catabolism and the growth of IDO-expressing tumors. Molecular Cancer Therapeutics. 2010; 9(2):489-498. doi: 10.1158/1535-7163.MCT-09-0628. [PubMed: 20124451]

127. Soliman H, Mediavilla-Varela M, Antonia S. Indoleamine 2,3-dioxygenase: is it an immune suppressor? Cancer Journal. 2010; 16(4):354-359.

128. Cady SG, Sono M. 1-Methyl-DL-tryptophan, beta-(3-benzofuranyl)-DL-alanine (the oxygen analog of tryptophan), and beta-[3-benzo(b)thienyl]-DL-alanine (the sulfur analog of tryptophan) are competitive inhibitors for indoleamine 2,3-dioxygenase. Archives of Biochemistry and Biophysics. 1991; 291(2):326-333. [PubMed: 1952947]

129. Hou DY, Muller AJ, Sharma MD, DuHadaway J, Banerjee T, Johnson M, et al. Inhibition of indoleamine 2,3-dioxygenase in dendritic cells by stereoisomers of 1-methyl-tryptophan correlates with antitumor responses. Cancer Research. 2007; 67(2):792-801. doi: 10.1158/0008-5472.CAN-06-2925. [PubMed: 17234791]

130. Metz R, Duhadaway JB, Kamasani U, Laury-Kleintop L, Muller AJ, Prendergast GC. Novel tryptophan catabolic enzyme IDO2 is the preferred biochemical target of the antitumor indoleamine 2,3-dioxygenase inhibitory compound D-1-methyl-tryptophan. Cancer Research. 2007; 67(15):7082-7087. doi:10.1158/0008-5472.CAN-07-1872. [PubMed: 17671174]

131. Opitz CA, Litzenburger UM, Sahm F, Ott M, Tritschler I, Trump S, et al. An endogenous tumourpromoting ligand of the human aryl hydrocarbon receptor. Nature. 2011; 478(7368):197-203. doi:10.1038/nature10491. [PubMed: 21976023]

132. Quintana FJ, Basso AS, Iglesias AH, Korn T, Farez MF, Bettelli E, et al. Control of T(reg) and $\mathrm{T}(\mathrm{H}) 17$ cell differentiation by the aryl hydrocarbon receptor. Nature. 2008; 453(7191):65-71. doi:10.1038/nature06880. [PubMed: 18362915]

133. Pilotte L, Larrieu P, Stroobant V, Colau D, Dolusic E, Frederick R, et al. Reversal of tumoral immune resistance by inhibition of tryptophan 2,3-dioxygenase. Proceedings of the National Academy of Sciences of the United States of America. 2012; 109(7):2497-2502. doi:10.1073/ pnas.1113873109. [PubMed: 22308364]

134. Kulbe H, Chakravarty P, Leinster DA, Charles KA, Kwong J, Thompson RG, et al. A dynamic inflammatory cytokine network in the human ovarian cancer microenvironment. Cancer Research. 2012; 72(1):66-75. doi:10.1158/0008-5472.CAN-11-2178. [PubMed: 22065722]

135. Kulbe H, Thompson R, Wilson JL, Robinson S, Hagemann T, Fatah R, et al. The inflammatory cytokine tumor necrosis factor-alpha generates an autocrine tumor-promoting network in epithelial ovarian cancer cells. Cancer Research. 2007; 67(2):585-592. doi: 10.1158/0008-5472.CAN-06-2941. [PubMed: 17234767]

136. Balkwill F. Tumor necrosis factor or tumor promoting factor? Cytokine \& Growth Factor Reviews. 2002; 13(2):135-141. doi:10.1016/s1359-6101(01)00020-x. [PubMed: 11900989]

137. Anderson GM, Nakada MT, DeWitte M. Tumor necrosis factor-alpha in the pathogenesis and treatment of cancer. Current Opinion in Pharmacology. 2004; 4(4):314-320. doi:10.1016/j.coph. 2004.04.004. [PubMed: 15251122]

138. Penson RT, Kronish K, Duan Z, Feller AJ, Stark P, Cook SE, et al. Cytokines IL-1beta, IL-2, IL-6, IL-8, MCP-1, GM-CSF and TNFalpha in patients with epithelial ovarian cancer and their relationship to treatment with paclitaxel. International Journal of Gynecological Cancer. 2000; 10(1):33-41. doi:10.1046/j.1525-1438.2000.00003.x. [PubMed: 11240649]

139. Guo Y, Xu F, Lu T, Duan Z, Zhang Z. Interleukin-6 signaling pathway in targeted therapy for cancer. Cancer Treatment Reviews. 2012; 38(7):904-9. doi:10. doi:10.1016/j.ctrv.2012.04.007. [PubMed: 22651903] 
140. Coward J, Kulbe H, Chakravarty P, Leader D, Vassileva V, Leinster DA, et al. Interleukin-6 as a therapeutic target in human ovarian cancer. Clinical Cancer Research. 2011; 17(18):6083-6096. doi:10.1158/1078-0432.CCR-11-0945. [PubMed: 21795409]

141. Duan Z, Foster R, Bell DA, Mahoney J, Wolak K, Vaidya A, et al. Signal transducers and activators of transcription 3 pathway activation in drug-resistant ovarian cancer. Clinical Cancer Research. 2006; 12(17):5055-5063. doi:10.1158/1078-0432.CCR-06-0861. [PubMed: 16951221]

142. Lo CW, Chen MW, Hsiao M, Wang S, Chen CA, Hsiao SM, et al. IL-6 trans-signaling in formation and progression of malignant ascites in ovarian cancer. Cancer Research. 2011; 71(2): 424-434. doi:10.1158/0008-5472.CAN-10-1496. [PubMed: 21123455]

143. Plante M, Rubin SC, Wong GY, Federici MG, Finstad CL, Gastl GA. Interleukin-6 level in serum and ascites as a prognostic factor in patients with epithelial ovarian cancer. Cancer. 1994; 73(7): 1882-1888. doi:10.1002/1097-0142(19940401)73:7<1882::aid-cncr2820730718>3.0.co;2-r. [PubMed: 8137215]

144. Yang L, Wang L, Lin HK, Kan PY, Xie S, Tsai MY, et al. Interleukin-6 differentially regulates androgen receptor transactivation via PI3K-Akt, STAT3, and MAPK, three distinct signal pathways in prostate cancer cells. Biochemical and Biophysical Research Communications. 2003; 305(3):462-469. doi:10.1016/s0006-291x(03)00792-7. [PubMed: 12763015]

145. Wang TH, Chan YH, Chen CW, Kung WH, Lee YS, Wang ST, et al. Paclitaxel (Taxol) upregulates expression of functional interleukin-6 in human ovarian cancer cells through multiple signaling pathways. Oncogene. 2006; 25(35):4857-4866. [PubMed: 16547493]

146. Stone RL, Nick AM, McNeish IA, Balkwill F, Han HD, Bottsford-Miller J, et al. Paraneoplastic thrombocytosis in ovarian cancer. The New England Journal of Medicine. 2012; 366(7):610-618. doi:10.1056/NEJMoa1110352. [PubMed: 22335738]

147. Trikha M, Corringham R, Klein B, Rossi JF. Targeted anti-interleukin-6 monoclonal antibody therapy for cancer: a review of the rationale and clinical evidence. Clinical Cancer Research. 2003; 9(13):4653-4665. [PubMed: 14581334]

148. Barbieri F, Bajetto A, Florio T. Role of chemokine network in the development and progression of ovarian cancer: a potential novel pharmacological target. Journal of Oncology. 2010; 2010:426956. doi:10.1155/2010/426956. [PubMed: 20049170]

149. Kryczek I, Lange A, Mottram P, Alvarez X, Cheng P, Hogan M, et al. CXCL12 and vascular endothelial growth factor synergistically induce neoangiogenesis in human ovarian cancers. Cancer Research. 2005; 65(2):465-472. [PubMed: 15695388]

150. Porcile C, Bajetto A, Barbieri F, Barbero S, Bonavia R, Biglieri M, et al. Stromal cell-derived factor-1alpha (SDF-1alpha/CXCL12) stimulates ovarian cancer cell growth through the EGF receptor transactivation. Experimental Cell Research. 2005; 308(2):241-253. doi:10.1016/ j.yexcr.2005.04.024. [PubMed: 15921680]

151. Kajiyama H, Shibata K, Terauchi M, Ino K, Nawa A, Kikkawa F. Involvement of SDF-1alpha/ CXCR4 axis in the enhanced peritoneal metastasis of epithelial ovarian carcinoma. International Journal of Cancer. 2008; 122(1):91-99. doi:10.1002/ijc.23083.

152. Righi E, Kashiwagi S, Yuan J, Santosuosso M, Leblanc P, Ingraham R, et al. CXCL12/CXCR4 blockade induces multimodal antitumor effects that prolong survival in an immunocompetent mouse model of ovarian cancer. Cancer Research. 2011; 71(16):5522-5534. doi: 10.1158/0008-5472.CAN-10-3143. [PubMed: 21742774]

153. Goode EL, Maurer MJ, Sellers TA, Phelan CM, Kalli KR, Fridley BL, et al. Inherited determinants of ovarian cancer survival. Clinical Cancer Research. 2010; 16(3):995-1007. doi: 10.1158/1078-0432.CCR-09-2553. [PubMed: 20103664]

154. Frede S, Freitag P, Otto T, Heilmaier C, Fandrey J. The proinflammatory cytokine interleukin 1 beta and hypoxia cooperatively induce the expression of adrenomedullin in ovarian carcinoma cells through hypoxia inducible factor 1 activation. Cancer Research. 2005; 65(11):4690-4697. doi:10.1158/0008-5472.CAN-04-3877. [PubMed: 15930287]

155. Ioana Braicu E, Mustea A, Toliat MR, Pirvulescu C, Konsgen D, Sun P, et al. Polymorphism of IL-1alpha, IL-1beta and IL-10 in patients with advanced ovarian cancer: results of a prospective study with 147 patients. Gynecologic Oncology. 2007; 104(3):680-685. doi:10.1016/j.ygyno. 2006.doi:10.014. [PubMed: 17141301] 
156. Goode EL, DeRycke M, Kalli KR, Oberg AL, Cunningham JM, Maurer MJ, et al. Inherited variants in regulatory T cell genes and outcome of ovarian cancer. PloS One. 2013; 8(1):e53903. doi:10.1371/journal.pone.0053903. [PubMed: 23382860]

157. Charbonneau B, Moysich KB, Kalli KR, Oberg AL, Vierkant RA, Fogarty ZC, et al. Large-scale evaluation of common variation in regulatory $\mathrm{T}$ cell-related genes and ovarian cancer outcome. Cancer Immunology Research. 2014; 2(4):332-340. doi:10.1158/2326-6066.CIR-13-0136. [PubMed: 24764580]

158. Ayyoub M, Pignon P, Classe JM, Odunsi K, Valmori D. CD4+ T Effectors Specific for the Tumor Antigen NY-ESO-1 Are Highly Enriched at Ovarian Cancer Sites and Coexist with, but Are Distinct from, Tumor-Associated Treg. Cancer Immunology Research. 2013; 1(5):303-308. doi:10.1158/2326-6066.CIR-13-0062-T. [PubMed: 24777968]

159. Wick DA, Webb JR, Nielsen JS, Martin SD, Kroeger DR, Milne K, et al. Surveillance of the tumor mutanome by $\mathrm{T}$ cells during progression from primary to recurrent ovarian cancer. Clinical Cancer Research. 2014; 20(5):1125-1134. doi:10.1158/1078-0432.CCR-13-2147. [PubMed: 24323902]

160. Ioannides CG, Fisk B, Fan D, Biddison WE, Wharton JT, O'Brian CA. Cytotoxic T cells isolated from ovarian malignant ascites recognize a peptide derived from the HER-2/neu proto-oncogene. Cellular Immunology. 1993; 151(1):225-234. doi:10.1006/cimm.1993.1233. [PubMed: 7691418]

161. Doherty JK, Bond C, Jardim A, Adelman JP, Clinton GM. The HER-2/neu receptor tyrosine kinase gene encodes a secreted autoinhibitor. Proceedings of the National Academy of Sciences of the United States of America. 1999; 96(19):10869-10874. [PubMed: 10485918]

162. Bookman MA, Darcy KM, Clarke-Pearson D, Boothby RA, Horowitz IR. Evaluation of monoclonal humanized anti-HER2 antibody, trastuzumab, in patients with recurrent or refractory ovarian or primary peritoneal carcinoma with overexpression of HER2: a phase II trial of the Gynecologic Oncology Group. Journal of Clinical Oncology. 2003; 21(2):283-290. [PubMed: 12525520]

163. Camilleri-Broet S, Hardy-Bessard AC, Le Tourneau A, Paraiso D, Levrel O, Leduc B, et al. HER-2 overexpression is an independent marker of poor prognosis of advanced primary ovarian carcinoma: a multicenter study of the GINECO group. Annals of Oncology. 2004; 15(1):104112. [PubMed: 14679128]

164. Karaferic A, Jovanovic D, Jelic S. Expression of HER2/neu, estrogen and progesterone receptors, CA 125 and CA19-9 on cancer cell membrane in patients with serous and mucinous carcinoma of the ovary. Journal of B.U.ON. 2009; 14(4):635-639. [PubMed: 20148455]

165. Tuefferd M, Couturier J, Penault-Llorca F, Vincent-Salomon A, Broet P, Guastalla JP, et al. HER2 status in ovarian carcinomas: a multicenter GINECO study of 320 patients. PloS One. 2007; 2(11):e1138. doi:10.1371/journal.pone.0001138. [PubMed: 17987122]

166. Hogdall EV, Christensen L, Kjaer SK, Blaakaer J, Bock JE, Glud E, et al. Distribution of HER-2 overexpression in ovarian carcinoma tissue and its prognostic value in patients with ovarian carcinoma: from the Danish MALOVA Ovarian Cancer Study. Cancer. 2003; 98(1):66-73. doi: 10.1002/cncr.11476. [PubMed: 12833457]

167. Baron-Hay S, Boyle F, Ferrier A, Scott C. Elevated serum insulin-like growth factor binding protein-2 as a prognostic marker in patients with ovarian cancer. Clinical Cancer Research. 2004; 10(5):1796-1806. [PubMed: 15014034]

168. Lancaster JM, Sayer RA, Blanchette C, Calingaert B, Konidari I, Gray J, et al. High expression of insulin-like growth factor binding protein-2 messenger RNA in epithelial ovarian cancers produces elevated preoperative serum levels. International Journal of Gynecological Cancer. 2006; 16(4):1529-1535. doi:10.1111/j.1525-1438.2006.00623.x. [PubMed: 16884361]

169. Wang H, Rosen DG, Wang H, Fuller GN, Zhang W, Liu J. Insulin-like growth factor-binding protein 2 and 5 are differentially regulated in ovarian cancer of different histologic types. Modern Pathology. 2006; 19(9):1149-1156. doi:10.1038/modpathol.3800637. [PubMed: 16729015]

170. Yan XJ, Tian Y, Wang C, Wang XL, Di JM, Cheng JX. [The expressions and clinical significance of IGFBP-2, -3 in both serum and tumor tissues in patients with epithelial ovarian cancer]. Sichuan Da Xue Xue Bao Yi Xue Ban. 2009; 40(4):639-643. [PubMed: 19764562]

171. Kalli KR, Krco CJ, Hartmann LC, Goodman K, Maurer MJ, Yu C, et al. An HLA-DR-degenerate epitope pool detects insulin-like growth factor binding protein 2-specific immunity in patients 
with cancer. Cancer Research. 2008; 68(12):4893-4901. doi:10.1158/0008-5472.CAN-07-6726. [PubMed: 18559537]

172. Bafna S, Singh AP, Moniaux N, Eudy JD, Meza JL, Batra SK. MUC4, a multifunctional transmembrane glycoprotein, induces oncogenic transformation of NIH3T3 mouse fibroblast cells. Cancer Research. 2008; 68(22):9231-9238. doi:10.1158/0008-5472.CAN-08-3135. [PubMed: 19010895]

173. Senapati S, Sharma P, Bafna S, Roy HK, Batra SK. The MUC gene family: their role in the diagnosis and prognosis of gastric cancer. Histology and Histopathology. 2008; 23(12):15411552. [PubMed: 18830939]

174. Chauhan SC, Singh AP, Ruiz F, Johansson SL, Jain M, Smith LM, et al. Aberrant expression of MUC4 in ovarian carcinoma: diagnostic significance alone and in combination with MUC1 and MUC16 (CA125). Modern Pathology. 2006; 19(10):1386-1394. doi:10.1038/modpathol. 3800646. [PubMed: 16880776]

175. Singh AP, Chauhan SC, Bafna S, Johansson SL, Smith LM, Moniaux N, et al. Aberrant expression of transmembrane mucins, MUC1 and MUC4, in human prostate carcinomas. The Prostate. 2006; 66(4):421-429. doi:10.1002/pros.20372. [PubMed: 16302265]

176. Bast RC Jr. Xu FJ, Yu YH, Barnhill S, Zhang Z, Mills GB. CA 125: the past and the future. The International Journal of Biological Markers. 1998; 13(4):179-187. [PubMed: 10228898]

177. Yin BW, Lloyd KO. Molecular cloning of the CA125 ovarian cancer antigen: identification as a new mucin, MUC16. The Journal of Biological Chemistry. 2001; 276(29):27371-27375. doi: 10.1074/jbc.M103554200. [PubMed: 11369781]

178. Ponnusamy MP, Lakshmanan I, Jain M, Das S, Chakraborty S, Dey P, et al. MUC4 mucininduced epithelial to mesenchymal transition: a novel mechanism for metastasis of human ovarian cancer cells. Oncogene. 2010; 29(42):5741-5754. doi:10.1038/onc.20doi:10.309. [PubMed: 20697346]

179. Terry KL, Titus-Ernstoff L, McKolanis JR, Welch WR, Finn OJ, Cramer DW. Incessant ovulation, mucin 1 immunity, and risk for ovarian cancer. Cancer Epidemiology Biomarkers \& Prevention. 2007; 16(1):30-35. doi:10.1158/1055-9965.EPI-06-0688.

180. Oei AL, Moreno M, Verheijen RH, Sweep FC, Thomas CM, Massuger LF, et al. Induction of IgG antibodies to MUC1 and survival in patients with epithelial ovarian cancer. International Journal of Cancer. 2008; 123(8):1848-1853. doi:10.1002/ijc.23725.

181. Plisiecka-Halasa J, Dansonka-Mieszkowska A, Kraszewska E, Danska-Bidzinska A, Kupryjanczyk J. Loss of heterozygosity, microsatellite instability and TP53 gene status in ovarian carcinomas. Anticancer Research, 28(2A). 2008:989-996.

182. Corney DC, Flesken-Nikitin A, Choi J, Nikitin AY. Role of p53 and Rb in ovarian cancer. Advances in Experimental Medicine and Biology. 2008; 622:99-117. doi: 10.1007/978-0-387-68969-2_9. [PubMed: 18546622]

183. Lambeck A, Leffers N, Hoogeboom BN, Sluiter W, Hamming I, Klip H, et al. P53-specific T cell responses in patients with malignant and benign ovarian tumors: implications for p53 based immunotherapy. International Journal of Cancer. 2007; 121(3):606-614. doi:10.1002/ijc.227doi: 10.

184. Valmori D, Qian F, Ayyoub M, Renner C, Merlo A, Gnjatic S, et al. Expression of synovial sarcoma X (SSX) antigens in epithelial ovarian cancer and identification of SSX-4 epitopes recognized by CD4+ T cells. Clinical Cancer Research. 2006; 12(2):398-404. doi: 10.1158/1078-0432.CCR-05-1902. [PubMed: 16428478]

185. Zhang S, Zhou X, Yu H, Yu Y. Expression of tumor-specific antigen MAGE, GAGE and BAGE in ovarian cancer tissues and cell lines. BMC Cancer. 2010; 10:163. doi: 10.1186/1471-2407-10-163. [PubMed: 20423514]

186. Hofmann M, Ruschenburg I. mRNA detection of tumor-rejection genes BAGE, GAGE, and MAGE in peritoneal fluid from patients with ovarian carcinoma as a potential diagnostic tool. Cancer. 2002; 96(3):187-193. doi:10.1002/cncr.10622. [PubMed: 12115308]

187. Straughn JM Jr. Shaw DR, Guerrero A, Bhoola SM, Racelis A, Wang Z, et al. Expression of sperm protein 17 (Sp17) in ovarian cancer. International Journal of Cancer. 2004; 108(6):805811. doi:10.1002/ijc.11617. 
188. Odunsi K, Jungbluth AA, Stockert E, Qian F, Gnjatic S, Tammela J, et al. NY-ESO-1 and LAGE-1 cancer-testis antigens are potential targets for immunotherapy in epithelial ovarian cancer. Cancer Research. 2003; 63(18):6076-6083. [PubMed: 14522938]

189. Agarwal S, Saini S, Parashar D, Verma A, Sinha A, Jagadish N, et al. The novel cancer-testis antigen A-kinase anchor protein 4 (AKAP4) is a potential target for immunotherapy of ovarian serous carcinoma. Oncoimmunology. 2013; 2(5):e24270. doi:10.4161/onci.24270. [PubMed: 23762804]

190. Li FQ, Han YL, Liu Q, Wu B, Huang WB, Zeng SY. Overexpression of human sperm protein 17 increases migration and decreases the chemosensitivity of human epithelial ovarian cancer cells. BMC Cancer. 2009; 9:323. doi:10.1186/1471-2407-9-323. [PubMed: 19744347]

191. Brown Jones M, Neuper C, Clayton A, Mariani A, Konecny G, Thomas MB, et al. Rationale for folate receptor alpha targeted therapy in "high risk" endometrial carcinomas. International Journal of Cancer. 2008; 123(7):1699-1703.

192. Dainty LA, Risinger JI, Morrison C, Chandramouli GV, Bidus MA, Zahn C, et al. Overexpression of folate binding protein and mesothelin are associated with uterine serous carcinoma. Gynecologic Oncology. 2007; 105(3):563-570. doi:10.1016/j.ygyno.2006.doi:10.063. [PubMed: 17400285]

193. Elnakat H, Ratnam M. Role of folate receptor genes in reproduction and related cancers. Frontiers in Bioscience, 11. 2006:506-519.

194. Parker N, Turk MJ, Westrick E, Lewis JD, Low PS, Leamon CP. Folate receptor expression in carcinomas and normal tissues determined by a quantitative radioligand binding assay. Analytical Biochemistry. 2005; 338(2):284-293. doi:10.1016/j.ab.2004.12.026. [PubMed: 15745749]

195. Kelemen LE. The role of folate receptor alpha in cancer development, progression and treatment: cause, consequence or innocent bystander? International Journal of Cancer. 2006; 119(2):243250. doi:10.1002/ijc.21712.

196. Peoples GE, Anderson BW, Fisk B, Kudelka AP, Wharton JT, Ioannides CG. Ovarian cancerassociated lymphocyte recognition of folate binding protein peptides. Annals of Surgical Oncology. 1998; 5(8):743-750. [PubMed: 9869522]

197. Peoples GE, Anderson BW, Lee TV, Murray JL, Kudelka AP, Wharton JT, et al. Vaccine implications of folate binding protein, a novel cytotoxic T lymphocyte-recognized antigen system in epithelial cancers. Clinical Cancer Research. 1999; 5(12):4214-4223. [PubMed: 10632363]

198. Tassi RA, Calza S, Ravaggi A, Bignotti E, Odicino FE, Tognon G, et al. Mammaglobin B is an independent prognostic marker in epithelial ovarian cancer and its expression is associated with reduced risk of disease recurrence. BMC cancer. 2009; 9:253. doi:10.1186/1471-2407-9-253. [PubMed: 19635143]

199. Tassi RA, Bignotti E, Falchetti M, Calza S, Ravaggi A, Rossi E, et al. Mammaglobin B expression in human endometrial cancer. International Journal of Gynecological Cancer. 2008; 18(5):1090-1096. doi:10.1111/j.1525-1438.2007.01137.x. [PubMed: 18021217]

200. Tassi RA, Bignotti E, Rossi E, Falchetti M, Donzelli C, Calza S, et al. Overexpression of mammaglobin B in epithelial ovarian carcinomas. Gynecologic oncology. 2007; 105(3):578-585. doi:10.1016/j.ygyno.2007.01.043. [PubMed: 17343903]

201. Bellone S, Tassi R, Betti M, English D, Cocco E, Gasparrini S, et al. Mammaglobin B (SCGB2A1) is a novel tumour antigen highly differentially expressed in all major histological types of ovarian cancer: implications for ovarian cancer immunotherapy. British Journal of Cancer. 2013; 109(2):462-471. doi:10.1038/bjc.2013.315. [PubMed: 23807163]

202. Pastan I, Hassan R. Discovery of Mesothelin and Exploiting it as a Target for Immunotherapy. Cancer Research. 2014; 74:2907-2912. [PubMed: 24824231]

203. Frierson HF Jr. Moskaluk CA, Powell SM, Zhang H, Cerilli LA, Stoler MH, et al. Large-scale molecular and tissue microarray analysis of mesothelin expression in common human carcinomas. Human Pathology. 2003; 34(6):605-609. [PubMed: 12827615]

204. Ho M, Hassan R, Zhang J, Wang QC, Onda M, Bera T, et al. Humoral immune response to mesothelin in mesothelioma and ovarian cancer patients. Clinical Cancer Research. 2005; 11(10): 3814-3820. doi:10.1158/1078-0432.CCR-04-2304. [PubMed: 15897581] 
205. Cheng WF, Huang CY, Chang MC, Hu YH, Chiang YC, Chen YL, et al. High mesothelin correlates with chemoresistance and poor survival in epithelial ovarian carcinoma. British Journal of Cancer. 2009; 100(7):1144-1153. doi:10.1038/sj.bjc.6604964. [PubMed: 19293794]

206. Kalli KR. MORAb-003, a fully humanized monoclonal antibody against the folate receptor alpha, for the potential treatment of epithelial ovarian cancer. Current Opinion in Investigational Drugs. 2007; 8(12):1067-1073. [PubMed: 18058577]

207. Ebel W, Routhier EL, Foley B, Jacob S, McDonough JM, Patel RK, et al. Preclinical evaluation of MORAb-003, a humanized monoclonal antibody antagonizing folate receptor-alpha. Cancer Immunity. 2007; 7:6. [PubMed: 17346028]

208. Smith-Jones PM, Pandit-Taskar N, Cao W, O'Donoghue J, Philips MD, Carrasquillo J, et al. Preclinical radioimmunotargeting of folate receptor alpha using the monoclonal antibody conjugate DOTA-MORAb-003. Nuclear Medicine and Biology. 2008; 35(3):343-351. doi: 10.1016/j.nucmedbio.2007.12.008. [PubMed: 18355690]

209. Armstrong DK, Coleman R, White AJ, Bicher A, Gibbon DG, Old LJ, et al. Efficacy and safety of farletuzumab, a humanized monoclonal antibody to folate receptor alpha, in platinum-sensitive relapsed ovarian cancer subjects: preliminary data from a phase-2 study. European Journal of Cancer. 2009; 7(2 Suppl):450.

210. White AJ, Coleman R, Armstrong DK, Glenn D, Bicher A, Richards DA, et al. Efficacy and safety of farletuzumab, a humanized monoclonal antibody to folate receptor alpha, in platinumsensitive relapsed ovarian cancer subjects: Final data from a multicenter phase II study. Journal of Clinical Oncology. 2010; 28(15_Suppl)

211. Spannuth WA, Sood AK, Coleman RL. Farletuzumab in epithelial ovarian carcinoma. Expert Opinion on Biological Therapy. 2010; 10(3):431-437. doi:10.1517/14712591003592069. [PubMed: 20092424]

212. Hudis CA. Trastuzumab--mechanism of action and use in clinical practice. The New England Journal of Medicine. 2007; 357(1):39-51. doi:10.1056/NEJMra043186. [PubMed: 17611206]

213. Ray-Coquard I, Guastalla JP, Allouache D, Combe M, Weber B, Cretin J, et al. HER2 Overexpression/Amplification and Trastuzumab Treatment in Advanced Ovarian Cancer: A GINECO Phase II Study. Clinical Ovarian Cancer. 2008; 1(1):54-59.

214. McAlpine JN, Wiegand KC, Vang R, Ronnett BM, Adamiak A, Kobel M, et al. HER2 overexpression and amplification is present in a subset of ovarian mucinous carcinomas and can be targeted with trastuzumab therapy. BMC Cancer. 2009; 9:433. doi:10.1186/1471-2407-9-433. [PubMed: 20003286]

215. Gordon MS, Matei D, Aghajanian C, Matulonis UA, Brewer M, Fleming GF, et al. Clinical activity of pertuzumab (rhuMAb 2C4), a HER dimerization inhibitor, in advanced ovarian cancer: potential predictive relationship with tumor HER2 activation status. Journal of Clinical Oncology. 2006; 24(26):4324-4332. doi:10.1200/JCO.2005.05.4221. [PubMed: 16896006]

216. Takai N, Jain A, Kawamata N, Popoviciu LM, Said JW, Whittaker S, et al. 2C4, a monoclonal antibody against HER2, disrupts the HER kinase signaling pathway and inhibits ovarian carcinoma cell growth. Cancer. 2005; 104(12):2701-2708. doi:10.1002/cncr.21533. [PubMed: 16265675]

217. Makhija S, Amler LC, Glenn D, Ueland FR, Gold MA, Dizon DS, et al. Clinical activity of gemcitabine plus pertuzumab in platinum-resistant ovarian cancer, fallopian tube cancer, or primary peritoneal cancer. Journal of Clinical Oncology. 2010; 28(7):1215-1223. doi:10.1200/ JCO.2009.22.3354. [PubMed: 19901115]

218. Kaye SB, Poole CJ, Danska-Bidzinska A, Gianni L, Del Conte G, Gorbunova V, et al. A randomized phase II study evaluating the combination of carboplatin-based chemotherapy with pertuzumab versus carboplatin-based therapy alone in patients with relapsed, platinum-sensitive ovarian cancer. Annals of Oncology. 2013; 24(1):145-152. doi:10.1093/annonc/mds282. [PubMed: 23002282]

219. Langdon SP, Faratian D, Nagumo Y, Mullen P, Harrison DJ. Pertuzumab for the treatment of ovarian cancer. Expert Opinion on Biological Therapy. 2010; 10(7):1113-1120. doi: 10.1517/14712598.20doi:10.487062. [PubMed: 20465533] 
220. Grisham RN, Berek J, Pfisterer J, Sabbatini P. Abagovomab: an anti-idiotypic CA-125 targeted immunotherapeutic agent for ovarian cancer. Immunotherapy. 2011; 3(2):153-162. doi:10.2217/ imt.doi:10.100. [PubMed: 21322756]

221. Wagner U, Kohler S, Reinartz S, Giffels P, Huober J, Renke K, et al. Immunological consolidation of ovarian carcinoma recurrences with monoclonal anti-idiotype antibody ACA125: immune responses and survival in palliative treatment. Clin. Cancer Res. 2001; 7:1112-1115. See The biology behind: K. A. Foon and M. Bhattacharya-Chatterjee, Are solid tumor anti-idiotype vaccines ready for prime time? 2001. Clinical Cancer Research 7(5), 1154-1162. [PubMed: 11350872]

222. Sabbatini P, Harter P, Scambia G, Sehouli J, Meier W, Wimberger P, et al. Abagovomab as maintenance therapy in patients with epithelial ovarian cancer: a phase III trial of the AGO OVAR, COGI, GINECO, and GEICO--the MIMOSA study. Journal of Clinical Oncology. 2013; 31(12):1554-1561. doi:10.1200/JCO.2012.46.4057. [PubMed: 23478059]

223. Berek J, Taylor P, McGuire W, Smith LM, Schultes B, Nicodemus CF. Oregovomab maintenance monoimmunotherapy does not improve outcomes in advanced ovarian cancer. Journal of Clinical Oncology. 2009; 27(3):418-425. doi:10.1200/JCO.2008.17.8400. [PubMed: 19075271]

224. Ehlen TG, Hoskins PJ, Miller D, Whiteside TL, Nicodemus CF, Schultes BC, et al. A pilot phase 2 study of oregovomab murine monoclonal antibody to CA125 as an immunotherapeutic agent for recurrent ovarian cancer. International Journal of Gynecological Cancer. 2005; 15(6):10231034. doi:10.1111/j.1525-1438.2005.00483.x. [PubMed: 16343178]

225. Berek JS, Taylor PT, Gordon A, Cunningham MJ, Finkler N, Orr J Jr. et al. Randomized, placebo-controlled study of oregovomab for consolidation of clinical remission in patients with advanced ovarian cancer. Journal of Clinical Oncology. 2004; 22(17):3507-3516. doi:10.1200/ JCO.2004.09.016. [PubMed: 15337799]

226. Ruf P, Gires O, Jager M, Fellinger K, Atz J, Lindhofer H. Characterisation of the new EpCAMspecific antibody HO-3: implications for trifunctional antibody immunotherapy of cancer. British Journal of Cancer. 2007; 97(3):315-321. doi:10.1038/sj.bjc.6603881. [PubMed: 17622246]

227. Burges A, Wimberger P, Kumper C, Gorbounova V, Sommer H, Schmalfeldt B, et al. Effective relief of malignant ascites in patients with advanced ovarian cancer by a trifunctional antiEpCAM x anti-CD3 antibody: a phase I/II study. Clinical Cancer Research. 2007; 13(13):38993905. doi:10.1158/1078-0432.CCR-06-2769. [PubMed: 17606723]

228. Heiss MM, Murawa P, Koralewski P, Kutarska E, Kolesnik OO, Ivanchenko VV, et al. The trifunctional antibody catumaxomab for the treatment of malignant ascites due to epithelial cancer: Results of a prospective randomized phase II/III trial. International Journal of Cancer. 2010; 127(9):2209-2221. doi:10.1002/ijc.25423.

229. Baumann K, Pfisterer J, Wimberger P, Burchardi N, Kurzeder C, du Bois A, et al. Intraperitoneal treatment with the trifunctional bispecific antibody Catumaxomab in patients with platinumresistant epithelial ovarian cancer: a phase IIa study of the AGO Study Group. Gynecologic Oncology. 2011; 123(1):27-32. doi:10.1016/j.ygyno.2011.06.004. [PubMed: 21733566]

230. Rossi JF, Negrier S, James ND, Kocak I, Hawkins R, Davis H, et al. A phase I/II study of siltuximab (CNTO 328), an anti-interleukin-6 monoclonal antibody, in metastatic renal cell cancer. British Journal of Cancer. 2010; 103(8):1154-1162. doi:10.1038/sj.bjc.6605872. [PubMed: 20808314]

231. Karkera J, Steiner H, Li W, Skradski V, Moser PL, Riethdorf S, et al. The anti-interleukin-6 antibody siltuximab down-regulates genes implicated in tumorigenesis in prostate cancer patients from a phase I study. The Prostate. 2011; 71(13):1455-1465. doi:10.1002/pros.21362. [PubMed: 21321981]

232. Fizazi K, De Bono JS, Flechon A, Heidenreich A, Voog E, Davis NB, et al. Randomised phase II study of siltuximab (CNTO 328), an anti-IL-6 monoclonal antibody, in combination with mitoxantrone/prednisone versus mitoxantrone/prednisone alone in metastatic castration-resistant prostate cancer. European Journal of Cancer. 2012; 48(1):85-93. doi:10.1016/j.ejca.2011.doi: 10.014. [PubMed: 22129890]

233. Dorff TB, Goldman B, Pinski JK, Mack PC, Lara PN Jr. Van Veldhuizen PJ Jr. et al. Clinical and correlative results of SWOG S0354: a phase II trial of CNTO328 (siltuximab), a monoclonal antibody against interleukin-6, in chemotherapy-pretreated patients with castration-resistant 
prostate cancer. Clinical Cancer Research. 2010; 16(11):3028-3034. doi:

10.1158/1078-0432.CCR-09-3122. [PubMed: 20484019]

234. Angevin E, Tabernero J, Elez E, Cohen SJ, Bahleda R, van Laethem JL, et al. A phase I/II, multiple-dose, dose-escalation study of siltuximab, an anti-interleukin- 6 monoclonal antibody, in patients with advanced solid tumors. Clinical Cancer Research. 2014; 20(8):2192-2204. doi: 10.1158/1078-0432.CCR-13-2200. [PubMed: 24563479]

235. Hodi FS, Mihm MC, Soiffer RJ, Haluska FG, Butler M, Seiden MV, et al. Biologic activity of cytotoxic T lymphocyte-associated antigen 4 antibody blockade in previously vaccinated metastatic melanoma and ovarian carcinoma patients. Proceedings of the National Academy of Sciences of the United States of America. 2003; 100(8):4712-4717. doi:10.1073/pnas. 0830997100. [PubMed: 12682289]

236. Brahmer JR, Tykodi SS, Chow LQ, Hwu WJ, Topalian SL, Hwu P, et al. Safety and activity of anti-PD-L1 antibody in patients with advanced cancer. The New England Journal of Medicine. 2012; 366(26):2455-2465. doi:10.1056/NEJMoa1200694. [PubMed: 22658128]

237. Knutson KL, Wagner W, Disis ML. Adoptive T cell therapy of solid cancers. Cancer Immunology, Immunotherapy. 2006; 55(1):96-103. doi:10.1007/s00262-005-0706-1. [PubMed: 15891880]

238. Kalos M, June CH. Adoptive T cell transfer for cancer immunotherapy in the era of synthetic biology. Immunity. 2013; 39(1):49-60. doi:10.1016/j.immuni.2013.07.002. [PubMed: 23890063]

239. June $\mathrm{CH}$. Adoptive $\mathrm{T}$ cell therapy for cancer in the clinic. The Journal of Clinical Investigation. 2007; 117(6):1466-1476. doi:10.1172/JCI32446. [PubMed: 17549249]

240. June $\mathrm{CH}$. Principles of adoptive $\mathrm{T}$ cell cancer therapy. The Journal of Clinical Investigation. 2007; 117(5):1204-1212. doi:10.1172/JCI31446. [PubMed: 17476350]

241. Rosenberg SA, Dudley ME. Adoptive cell therapy for the treatment of patients with metastatic melanoma. Current Opinion in Immunology. 2009; 21(2):233-240. doi:10.1016/j.coi. 2009.03.002. [PubMed: 19304471]

242. Kershaw MH, Westwood JA, Parker LL, Wang G, Eshhar Z, Mavroukakis SA, et al. A phase I study on adoptive immunotherapy using gene-modified $\mathrm{T}$ cells for ovarian cancer. Clinical Cancer Research, 12(20 Pt 1). 2006:6106-6115. doi:10.1158/1078-0432.CCR-06-1183.

243. Dobrzanski MJ, Rewers-Felkins KA, Quinlin IS, Samad KA, Phillips CA, Robinson W, et al. Autologous MUC1-specific Th1 effector cell immunotherapy induces differential levels of systemic TReg cell subpopulations that result in increased ovarian cancer patient survival. Clinical Immunology. 2009; 133(3):333-352. doi:10.1016/j.clim.2009.08.007. [PubMed: 19762283]

244. Dobrzanski MJ, Rewers-Felkins KA, Samad KA, Quinlin IS, Phillips CA, Robinson W, et al. Immunotherapy with IL-10- and IFN-gamma-producing CD4 effector cells modulate "Natural" and "Inducible" CD4 TReg cell subpopulation levels: observations in four cases of patients with ovarian cancer. Cancer Immunology, Immunotherapy. 2012; 61(6):839-854. doi:10.1007/ s00262-011-1128-x. [PubMed: 22083345]

245. Wright SE, Rewers-Felkins KA, Quinlin IS, Phillips CA, Townsend M, Philip R, et al. Cytotoxic T-lymphocyte immunotherapy for ovarian cancer: a pilot study. Journal of Immunotherapy. 2012; 35(2):196-204. doi:10.1097/CJI.0b013e318243f213. [PubMed: 22306908]

246. Le DT, Brockstedt DG, Nir-Paz R, Hampl J, Mathur S, Nemunaitis J, et al. A live-attenuated Listeria vaccine (ANZ-100) and a live-attenuated Listeria vaccine expressing mesothelin (CRS-207) for advanced cancers: phase I studies of safety and immune induction. Clinical Cancer Research. 2012; 18(3):858-868. doi:10.1158/1078-0432.CCR-11-2121. [PubMed: 22147941]

247. Melief CJ, van der Burg SH. Immunotherapy of established (pre)malignant disease by synthetic long peptide vaccines. Nature Reviews Cancer. 2008; 8(5):351-360. doi:10.1038/nrc2373.

248. Sabbatini P, Tsuji T, Ferran L, Ritter E, Sedrak C, Tuballes K, et al. Phase I trial of overlapping long peptides from a tumor self-antigen and poly-ICLC shows rapid induction of integrated immune response in ovarian cancer patients. Clinical Cancer Research. 2012; 18(23):6497-6508. doi:10.1158/1078-0432.CCR-12-2189. [PubMed: 23032745] 
249. Kaumaya PT, Foy KC, Garrett J, Rawale SV, Vicari D, Thurmond JM, et al. Phase I active immunotherapy with combination of two chimeric, human epidermal growth factor receptor 2, Bcell epitopes fused to a promiscuous T-cell epitope in patients with metastatic and/or recurrent solid tumors. Journal of Clinical Oncology. 2009; 27(31):5270-5277. doi:10.1200/JCO. 2009.22.3883. [PubMed: 19752336]

250. Hernando JJ, Park TW, Fischer HP, Zivanovic O, Braun M, Polcher M, et al. Vaccination with dendritic cells transfected with mRNA-encoded folate-receptor-alpha for relapsed metastatic ovarian cancer. The Lancet Oncology. 2007; 8(5):451-454. doi:10.1016/ S1470-2045(07)70142-0. [PubMed: 17466904]

251. zum Buschenfelde CM, Hermann C, Schmidt B, Peschel C, Bernhard H. Antihuman epidermal growth factor receptor 2 (HER2) monoclonal antibody trastuzumab enhances cytolytic activity of class I-restricted HER2-specific T lymphocytes against HER2-overexpressing tumor cells. Cancer Research. 2002; 62(8):2244-2247. [PubMed: 11956077]

252. Disis ML, Wallace DR, Gooley TA, Dang Y, Slota M, Lu H, et al. Concurrent trastuzumab and HER2/neu-specific vaccination in patients with metastatic breast cancer. Journal of Clinical Oncology. 2009; 27(28):4685-4692. doi:10.1200/JCO.2008.20.6789. [PubMed: 19720923]

253. Muraoka-Cook RS, Dumont N, Arteaga CL. Dual role of transforming growth factor beta in mammary tumorigenesis and metastatic progression. Clinical Cancer Research. 2005; 11:937s943s. 2 Pt 2. [PubMed: 15701890]

254. Halder SK, Beauchamp RD, Datta PK. A specific inhibitor of TGF-beta receptor kinase, SB-431542, as a potent antitumor agent for human cancers. Neoplasia. 2005; 7(5):509-521. [PubMed: 15967103]

255. von Boehmer H. Mechanisms of suppression by suppressor T cells. Nature Immunology. 2005; 6(4):338-344. doi:10.1038/ni1180. [PubMed: 15785759] 


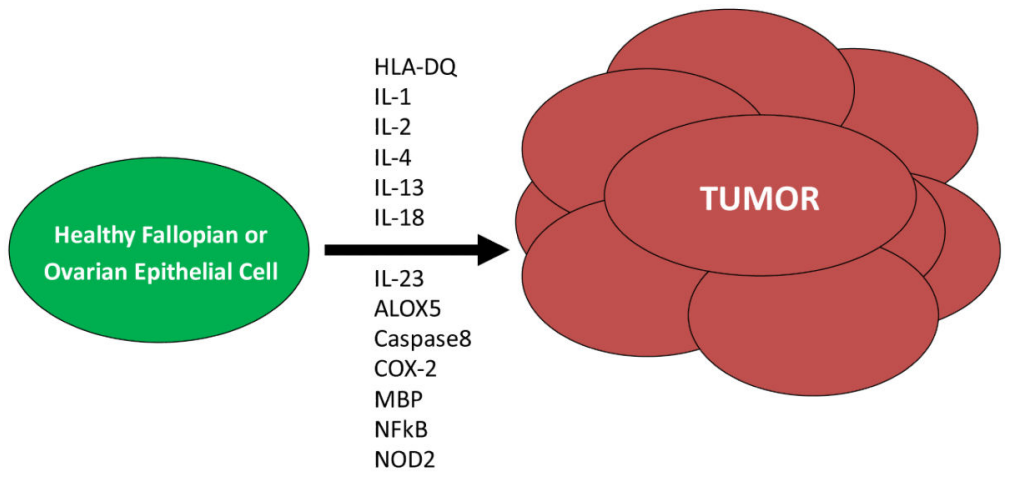

Figure 1.

Immune mediators are involved in initiating ovarian cancer 


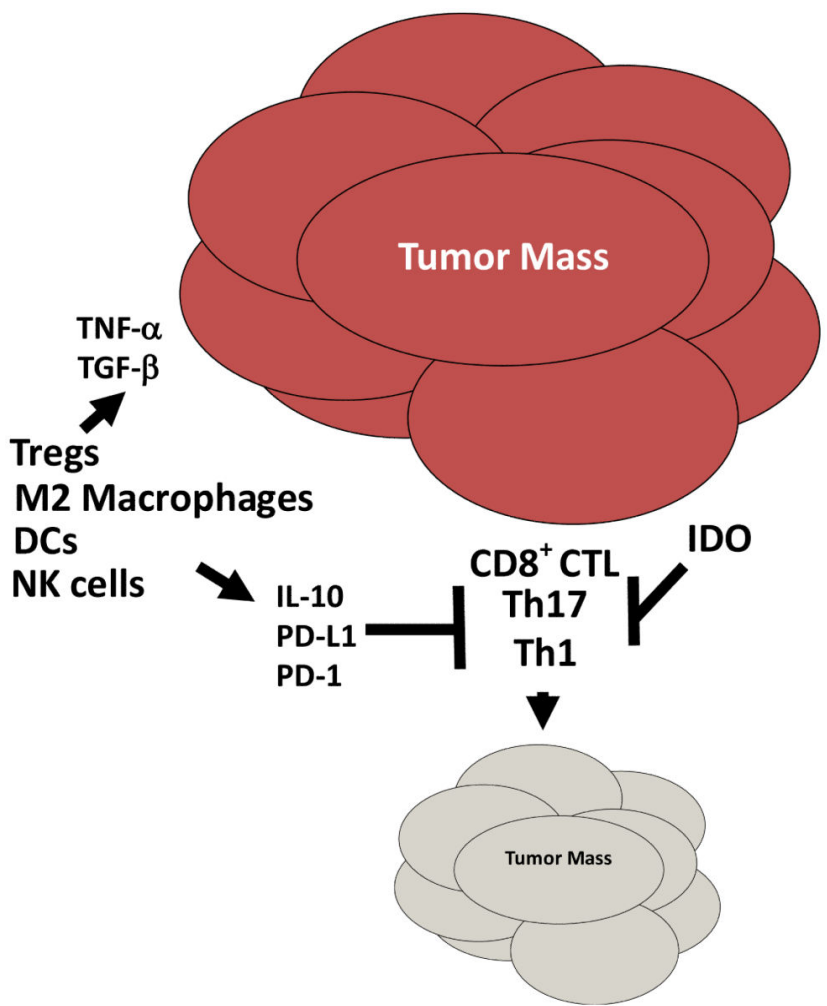

Figure 2.

The immune system favors tumor progression in ovarian cancer 


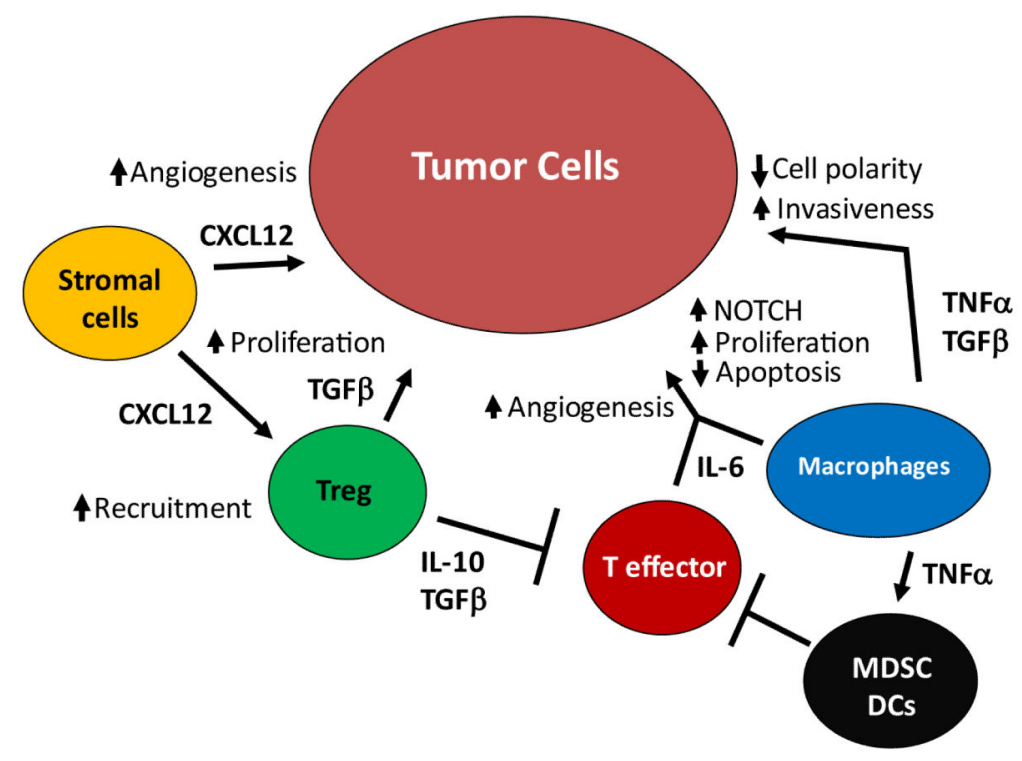

Figure 3.

The TNF network contributes to ovarian cancer pathogenesis 